$\xi^{2}=-1$

\title{
Syn-collisional pan-African granite in the northern part Birnin Gwari schist belt in NW Nigeria
}

\author{
Kehinde Oluyede $^{1 *}$, Urs Klötzli ${ }^{1}$ \\ ${ }^{1}$ Department of Geology, Ahmadu Bello University Zaria, Nigeria \\ ${ }^{2}$ Department of Lithospheric Research, University of Vienna, Austria \\ *Corresponding author E-mail: olulekeoluyede@gmail.com
}

\begin{abstract}
Syn-collisional granite in the northern part of the Birnin Gwari schist belt consists dominantly of granite and lesser granodiorite and quartzolite. Petrographic and ge $\neg$ ochemical data revealed three granite groups: the biotite-hornblende granite (quartzolite - BHG); the biotite granite (BG) and the biotite-muscovite granite (BMG). The rocks generally have calc-alkaline and high-K calc-alkaline affinities, and calc-alkalic to alkali-calcic, peraluminous and ferroan and magnesian geochemistry. They are characterized by LILE enrichment, high LREE fractionation factor [(La/Yb) $(6.74$ to 45.14$]$ with weak to moderate negative $\mathrm{Eu}\left(\mathrm{Eu} / \mathrm{Eu}^{*}=0.38\right.$ to 0.62$)$ and strong negative $\mathrm{Nb}, \mathrm{P}$ and Ti anomalies. Variation in the behavior of lithophile elements ( $\mathrm{Ba}, \mathrm{Sr}$ and $\mathrm{Rb}$ ) revealed diverse granite trend such as "high and low Ba-Sr"; "normal", "anomalous" "strongly differentiated" and "granodiorite and quartz diorite" granite. Their display of similar trace elements and REE patterns suggest they are cogenetic. Major and trace element data indicate differentiation of a mafic magma and partial melting of crustal components inherited from shale-greywacke and quartzose sedimentary protoliths in volcanic arc and post collisional settings. The field and geochemical characteristics of this granite suggest that they are similar to other granites in schist belts in other parts of Nigeria, forming the lateral continuation of the same Pan-African magmatic belt.
\end{abstract}

Keywords: Birnin Gwari; Calc-Alkaline; Granite; Nigeria; Quartzolite.

\section{Introduction}

Syn-collision granites in and around Birnin Gwari area constitute one of the three major rock units of the Precambrian Basement Complex rocks north of Birnin Gwari schist belt. The other units are the Migmatite-Gneiss-Quartzite suite represented by dioritic, granodioritic, granitic and granitic gneisses and Birnin Gwari schist belt represented biotite-staurolite quartz schist. Turner, (1983) and Ajibade et al. (2008) described the Birnin Gwari Schist belt and the underlying quartzo-feldspathic rocks of the Zungeru Formation as a simple N-S syncline, $150 \mathrm{~km}$ long, forming a single structural unit named Zungeru-Birnin Gwari Schist Belt. The northern part of the belt which is the study area (Fig. 1) is displaced dextrally by a NE-SW transcurrent fault and characterized by conspicuous NNE-SSW trending ridges rising over $100 \mathrm{~m}$ above the surrounding country, comprising mainly phyllites, mica schists, with which metagreywacke, pebbly schist and metavolcanics are interlayered. The lower part (south of the study area) consists of finely banded phyllites in the west and higher grade biotite-muscovite schists in the east, overlain by the Durimi pebbly schist, a metamorphosed mudstone conglomerate.

Published work on the rocks includes radiometric dating, structures and mineralization. Grant (1978) described the structures in this belt where he recognised a simple $\mathrm{N}-\mathrm{S}$ structural style, and $\mathrm{Rb}-\mathrm{Sr}$ whole rock data from the adjacent Zungeru mylonites have yielded ages varying from $600 \mathrm{Ma}-700 \mathrm{Ma}$. Radiometric age measurement of $\mathrm{Rb}-\mathrm{Sr}$ data from Kusheriki granite emplaced across the gneissic envelope gives an age of $500+4 \mathrm{Ma}$. which suggests Pan-African deformation and emplacement of the region (Ajibade et al., 1979; 2008). They described a complex structural sequence from parts of the neighbouring Birnin-Gwari Schist and Ushama Schist Formations and identified four deformation episodes that have affected the rocks in these areas and later define the Zungeru Mylonites. They also confirmed the presence of two types of migmatites and gneisses which are believed to belong to two different ages. Garba (2002) also revealed epigenetic gold-sulphide mineralization hosted by sub-parallel shear zones along isoclinal axes of tightly folded graphitic phyllites near Tsohon Birnin Gwari in the Kushaka schist belt similar to Bin Yauri area (Zuru schist belt) and other areas of Archaean and younger mesothermal gold mineralization in the world.

Previous published work on of the rocks close to the study area especially the Older Granites in Minna and Abuja focused on the geochemistry, geochronology and rare metal pegmatites (Ajibade et al. 2008; Goodenough et al. 2014). Little or no work has been done on the granitoids in this part of the Birnin Gwari schist belt. Geochemical data required for proper classification and characterization of these granitic rocks are generally scarce. In this work, major, trace and rare earth elements (REE) data on eight relatively unknown granitic plutons and four host rock (granite gneiss) have been used to assess their petrogenetic evolution and tectonic setting. 


\section{Regional geology}

The Nigerian basement complex consists of three major rock units: (1) the Migmatite Gneiss Quartzite Complex (MGQC) dated from Archean to Early Proterozoic (2700-2000 Ma), a heterogeneous assemblage of predominantly amphibolite-facies migmatites, orthogneisses, paragneisses, and minor-basic to ultrabasic rocks; (2) the N-S and NE-SW Schist Belts, believed to overlie the MGQC and consisting mainly of psammitic to pelitic metasediments with interlayered granitoid gneisses and rare amphibolites, interpreted as metavolcanics; and (3) Late Proterozoic to Early Phanerozoic (750-450Ma) Older Granites, intruding both 1 and 2 and composed of tonalitic to granitic plutons and charnockites, strongly foliated to almost unfoliated, and considered to have been emplaced during the Pan-African orogeny (Russ,1957; McCurry, 1976; Fitches, et al.1985; Rahaman 1976; 1988; Olanrewaju, 1988; Turner 1983; Oyinloye and Ojo, 1988; Tubosun et al. 1984).

The "Older Granites" of Nigeria include a wide spectrum of rocks varying in composition from tonalite through granodiorite to granite, syenite and charnokitic rocks. They have been described as calcalkaline, I-type granites (Olarewaju and Rahaman, 1982; Egbuniwe et al., 1985; Fitches et al., 1985). The syenites have mildly alkaline affinities (Egbuniwe et al., 1985). Typical minerals of metasedimentary rocks such as garnet and staurolite are also commonly encountered in some of the granitic rocks which are often weakly foliated. They are characterized by high grade metamorphism, folding, faulting and widespread granite plutonism. They have been dated repeatedly at 750-500Ma (van Breemen, 1977; Rahaman et al., 1983; Fitches, Ajibade, Egbuniwe, 1985; Ferre et al., 1998; Ekwueme \& Kroner, 1998) (Table 1). Similar granitic rocks have also been studied in various parts of the Nigerian basement complex, northern Nigeria (Olarewaju \& Rahaman, 1982), Jebba area (Okonkwo \& Winchester, 2004), Obudu Plateau, southeastern Nigeria (Ukwang \& Ekwueme, 2009), Kabba-Lokoja area (Ezepue \& Odigi, 1993), among others. Granite magmatism is commonly associated with several tectonic settings and various stages during orogenic evolution (Harris, Pearce \& Tindle, 1986; Maniar \& Piccoli, 1989).

In NW Nigeria the rocks include syenites and biotite granites. They have been described as calc-alkaline, I-type granites (Olarewaju and Rahaman, 1982; Egbuniwe et al., 1985; Fitches et al., 1985). In north-central Nigeria, they are Al-rich to slightly Al-excess granites, granodiorites, syenites, syenodiorites, and diorites derived through partial melting of crustal rocks (Onyeagocha, 1986; Obiora, 2012). In SW granites are felsic and intermediate alkali rich rocks of peraluminous, ferroan and magnesian character, and of non-oceanic origin, grouped as within plate granites (Igonor and Abimbola, 2016). The south-eastern margin of the southwestern sector in Idofin-Osi-Eruku area, granites are Fe-rich potassic calc-alkaline rock and products of syncollisional volcanic arc magmatism emplaced in the late phase of the Pan-African Orogeny (Odewumi and Olanrewaju, 2013). In the SE, granites are high-K calc-alkaline transalkaline to non-alkaline rock, with alkalic-calcic to alkalic, ferroan and metaluminous character derived from partial melting of hornblende-rich crustal sources in an orogenic (syn- to late/post-collisional) tectonic setting (Obiora, 2012). Other granitic rocks described according to their petrographic affinities are porphyritic granites, fine to medium grained granite, syenite, quartz syenite, quartz hypersthene granite and hypersthene granite as described by Oyawoye (1964; 1972) and Makanjuola (1982).

\section{Study area}

The study area covers a total area of 1,250 square kilometers and lies in the north western part of Nigeria comprising part of Kushaka and Birnin Gwari schist belts. It falls within 1:100,000 Kushaka Sheet 122 and bounded by latitudes $10^{\circ} 30^{\prime \prime} \mathrm{N}$ and $11^{\circ} 00^{\prime \prime} \mathrm{N}$ and longitudes $6^{0} 30^{\prime}$ 'E and $6^{0} 42^{\prime \prime}$ E (Fig. 1). The area is underlain predominantly by three main lithologies: (i) Migmatite-Gneiss-Quartzite suite represented by dioritic, granodioritic, granitic and granitic gneisses; the schist belts represented by (ii) biotite and staurolite quartz schist and (iii) syn-collision biotite granite (BG) and biotite-muscovite granite (BMG).

\section{Materials and methods}

Twelve representatives granite (eight in Kushaka pluton and four surrounding granitic gneisses) samples were carefully selected and thin sections were prepared and petrographic studies of different rock types were done using a petrographic research microscope at the Department of Geology, Ahmadu Bello University, Zaria. Modal compositions of the rocks were estimated from thin section studies using the JMicrovision software of Nicholas Roduit version 1.2.7. (2002-2008). Modal analyses of the granitoids are given in Table 1. These twelve samples were also analysed (Table 2). About $1 \mathrm{~kg}$ of each sample was broken into pieces with a hammer and crushed into smaller pieces with a jaw-crusher. The samples were thereafter pulverized in a disc mill for about two minutes. Each pulverised sample was thoroughly homogenized to obtain a representative portion. The samples were thereafter sent to laboratories for whole-rock geochemistry in the Department of Lithospheric Research, University of Vienna, Austria, while REE analyses were done at the MSALABS in Langley, British Columbia, Canada.

Rocks were crushed and grounded to the finest powder possible in an agate (or tungsten carbide) swing mill for the whole X-rayfluorescence analysis. Major elements were determined by the fused bead method on calcined rock powder fused with lithium tetraborate as flux to form a glass bead. Trace elements used the pressed pellet method directly on the crushed and milled rock powder mixed with polyvinyl alcohol as a binding agent. The element analyses are performed on a sequential X-Ray spectrometer PHILIPS PW2404 using a super-sharp end-window tube with a $\mathrm{Rh}$-anode and a programmable $4 \mathrm{~kW}$ generator (60kV max., $125 \mathrm{~mA}$ max.; iso-Watt-switching), with accompanying PANalytical software. REE analyses were done using a lithum metaborate/tetraborate flux in a platinum crucible and fused samples poured into a platinum mold to create a homogenous glass disk and then analysed by Xray-flourescence (XRF).

\section{Results}

\subsection{Field characteristics and petrography}

The granite plutons intruded both the Migmatite-Gneiss-Quartzite suite represented by dioritic, granodioritic, granitic and granitic gneisses and the Birnin Gwari schist in Gworon Dutse, Mando, Loko, Bagwoma, Birnin Gwari and Kugu. They are further sub-divided into: a) granodiorite (Birnin Gwari/Mando border); b) granite (Gworon Dutse coarse grained biotite and medium grained biotitemuscovite granite; Mando biotite-muscovite granite; Mando/Loko biotite-muscovite granite; Nassarawa Kwona biotite granite, Kugu biotite granite and Bagwoma quartzolite); c) host Gwaska granitic leucosome, Kampani Doka biotite and biotite-muscovite granite gneiss Kungwi biotite migmatitic gneiss). These intrusions form N-S oriented oval and elongated bodies of whaleback with moderate and high 
relief on either side of the transcurrent Kalangai fault (Fig. 1). The host granitic gneisses are characterized by gneissose foliation and migmatitic ones shows alternations of light and dark coloured bands. The light bands consist mainly of quartz and feldspars while the dark bands are enriched in biotite and muscovite. They are coarse porphyritic to medium grained rocks and generally devoid of pervasive foliation. The modal composition of granites in the Kushaka Schist Belt is given in Table 2 and Fig. 3.

\subsubsection{Granodiorite}

Granodiorite along the Birnin Gwari/ Mando axis is restricted to the contact zone between the Birnin Gwari staurolite bearing quartz schist and Mando biotite and muscovite granite. This is a medium grained rock characterized by light grey granitic inclusions in the lightbrown coloured rock slightly aligned in the N-S foliation direction. Under the microscope, it is a coarse to medium grained rock consisting of quartz $(30 \%)$, K-feldspar $(30 \%)$, plagioclase $(15 \%)$, biotite $(15 \%)$, and accessory minerals $(5 \%)$. The K-feldspars (orthoclase with little microcline) occur as platy subhedral grains with faint albite twinning; plagioclase occurs as platy euhedral to subhedral crystals. K-feldspar and plagioclase minerals are characterized by zoned and dense clay minerals generally ascribed to lowtemperature alteration. Anhedral biotite occurs in closely with iron-oxide and titanite and also forms part of the dense materials in the feldspars. Accessory minerals are titanite, magnetite, zircon and apatite.

\subsubsection{Granite}

Granite occur as N-S trending isolated plutons and low whale back outcrops on the edges of the Birnin Gwari schists in places with sharp contacts with the schists and granitic gneisses (Fig. 1). Granitoids in Goron Dutse consists of four individual closely spaced plutons, with high relief $(550 \mathrm{~m})$, and intruded the Birnin Gwari metasediments at the northwestern fringes. Two varieties

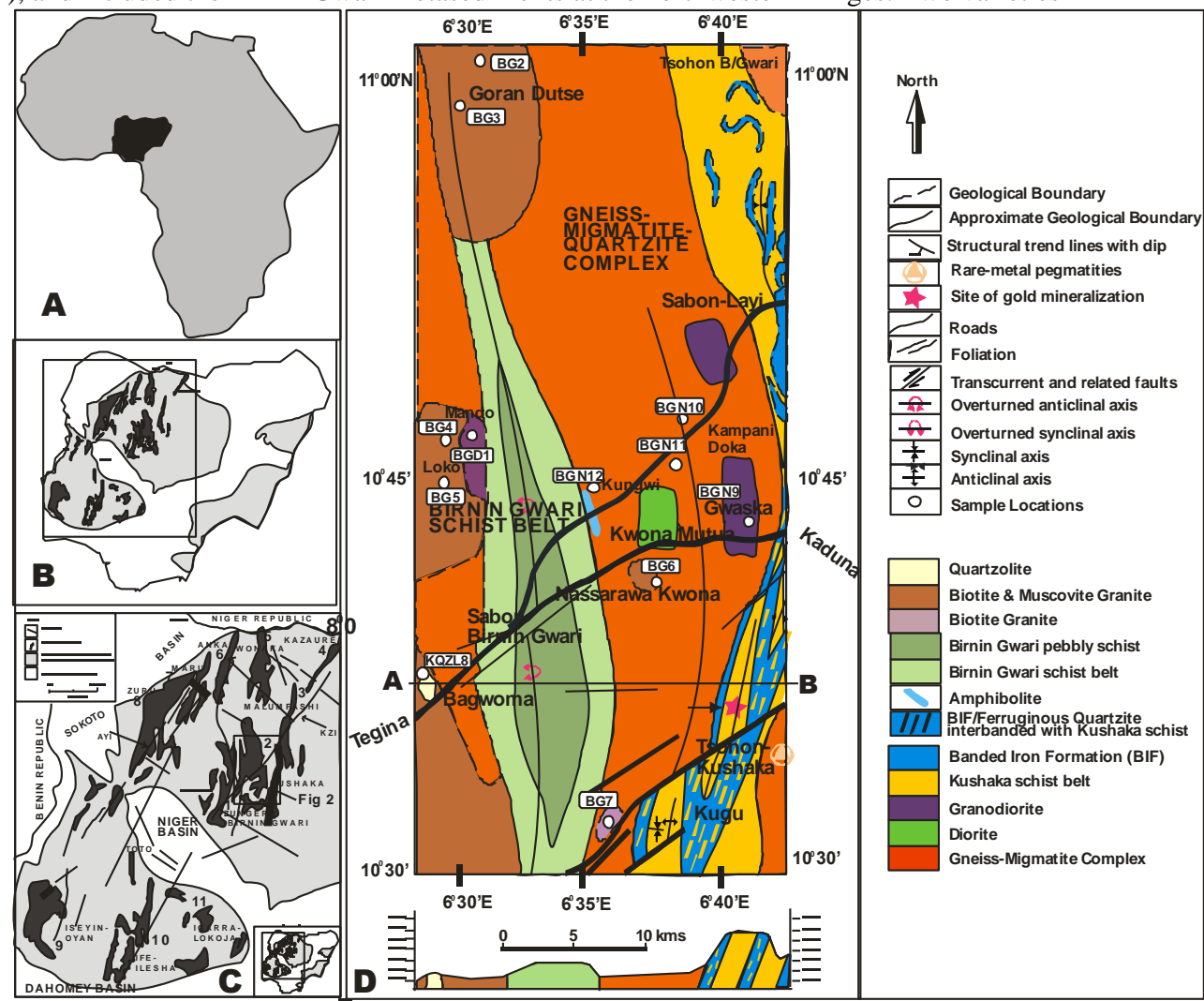

Fig. 1: Geological Map of Northern Part of Birnin Gwari Schist Belt (Sheet 122) Modified After Truswell and Cope, (1963).

are coarse porphyritic and fine- to medium grained equigranular types, occurring closely together and the latter as dykes and veins in the former. The coarse porphyritic types in hand specimen shows grey to light pink feldspar porphyries of $2-12 \mathrm{~mm}$ in diameter. Mafic minerals are biotite and muscovite, weakly foliated and trending $220^{\circ} \mathrm{NE}-\mathrm{SW}$. Under microscope, these rocks show granitic texture formed by pink K-feldspar phenocryst in quartz and feldspar matrix and associated with flaky and needle-like brown biotite. The coarse porphyritic type occurs as hypidiomorphic rock in which felsic minerals constitutes more than $60 \%$. Quartz forms about $35 \%$ and occurs as euhedral prismatic crystals filling the interstices of the orthoclase and stacked against each other. K-feldspar (40\%) occurs as orthoclase and microcline with large phenocryst showing micro-perthitic texture and with cracks across the cross hatch twinning. Some of the orthoclase contains dense mass of fine mica and clay minerals as alteration and small tabular muscovite inclusions. The cracks in the feldspars are filled with tiny rounded quartz and fibrous biotite minerals as well as opaque magnetite.

Table 1: Age Data on Some Granite and Migmatite Gneiss Host in the Nigerian Basement Complex

\begin{tabular}{lllll}
\hline Lithology & Geologic Age & Method & Epoch & Event/Author \\
\hline Southwest & & & & Metamorphism Tunbosun et al. \\
Akure gneissic Charnockite & $634 \mathrm{Ma}$ & U-Pb age & Pan-African & (1984) \\
Ikare massive Charnockite & $634 \mathrm{Ma}$ & U-Pb age & Pan-African & Intrusion Tunbosun et al.(1984) \\
Idanre massive charnokite & $593 \mathrm{Ma}$ & $\mathrm{U}-\mathrm{Pb}$ & Pan-African & Intrusion Tunbosun et al.(1984) \\
$\begin{array}{l}\text { Northwest } \\
\text { Kazaure Older Granite }\end{array}$ & $592+14$ & $\mathrm{Rb}-\mathrm{Sr}$ age & Pan-African & Intrusion Danbatta (2002) \\
Minna Granodiorite & $505+12$ & $\mathrm{Rb}-\mathrm{Sr}$ & Pan-African & Intrusion Ajibade (2008) \\
\hline
\end{tabular}




\begin{tabular}{|c|c|c|c|c|}
\hline Badiko syntectonic diorite & $623 \mathrm{Ma}$ & $\mathrm{U}-\mathrm{Pb}$ & Pan-African & Dada et al. (1993) \\
\hline $\begin{array}{l}\text { Minna Granodiorite } \\
\text { Southeast }\end{array}$ & $790-760 \mathrm{Ma}$ & $\mathrm{U}-\mathrm{Pb}$ zircon & Pan-African & Goodenough et al., 2014 \\
\hline $\begin{array}{l}\text { Granodiorite in banded gneiss from Oban } \\
\text { massif (Uwet) }\end{array}$ & $616.9+1 \mathrm{Ma}$ & $\begin{array}{l}\mathrm{Pb}-\mathrm{Pb} \text { single zircon } \\
\text { evaporation }\end{array}$ & Pan-African & $\begin{array}{l}\text { Intrusion Ekweme and Kroner } \\
\text { (1998) }\end{array}$ \\
\hline Granite from Mkar Gboko & $547+33 \mathrm{Ma}$ & $\begin{array}{l}\mathrm{Rb}-\mathrm{Sr} \text { whole rock } \\
\text { isochron }\end{array}$ & Pan-African & $\begin{array}{l}\text { Intrusion Umeji and Caen- } \\
\text { Vachette (1984) }\end{array}$ \\
\hline $\begin{array}{l}\text { Northeast } \\
\text { Toro Bauchite (Quartz fayalite } \\
\text { monzonite) }\end{array}$ & $638 \mathrm{Ma}$ & $\mathrm{U}-\mathrm{Pb}$ age & Pan-African & Dada et al., (1989) \\
\hline $\begin{array}{l}\text { Amp-bi-granite from Soli Hill and } \\
\text { Rahama }\end{array}$ & $\begin{array}{l}598+11 \mathrm{Ma} \text { and } 577+ \\
16 \mathrm{Ma}\end{array}$ & $\begin{array}{l}\mathrm{Pb}-\mathrm{Pb} \text { single zircon } \\
\text { evaporation }\end{array}$ & Pan-African & Intrusion Ferre et al., (1998) \\
\hline Metadiorite from Toro & $623+20 \mathrm{Ma}$ & $\begin{array}{l}\text { U-Pb zircon Upper } \\
\text { intercept }\end{array}$ & Pan-African & Metemorphism Lar (1988) \\
\hline \multicolumn{5}{|l|}{ North-central } \\
\hline Biotite granite from Nassarawa Eggon & $539+8 \mathrm{Ma}$ & $\mathrm{Rb}-\mathrm{Sr}$ biotite age & Pan-African & $\begin{array}{l}\text { Intrusion Umeji and Caen- } \\
\text { Vachette (1984) }\end{array}$ \\
\hline Panyam granite & $692+161 \mathrm{Ma}$ & $\mathrm{Rb}-\mathrm{Sr}$ isochron age & Pan-African & Van Breemen et al. (1977) \\
\hline \multicolumn{5}{|l|}{ Migmatite/Granitic Gneiss } \\
\hline Kaduna granodiorite gneiss & $3.46 \mathrm{Ga}$ & $\mathrm{U}-\mathrm{Pb}$ & $\begin{array}{l}\text { Pre-Pan- } \\
\text { African } \\
\text { Archean }\end{array}$ & Bruguier et al. (1994) \\
\hline Kaduna early gneiss & $3.1 \mathrm{Ga}$ & $\mathrm{U}-\mathrm{Pb}, \mathrm{Rb}-\mathrm{Sr}$ & $\begin{array}{l}\text { Pre-Pan- } \\
\text { African } \\
\text { Archean } \\
\text { Pre-Pan- }\end{array}$ & $\begin{array}{l}\text { Dada (1989). Bruguier et al. } \\
\text { (1994) }\end{array}$ \\
\hline Ife-Ilesha granite gneiss & $1.12 \mathrm{Ga}$ & $\mathrm{Rb}-\mathrm{Sr}$ & $\begin{array}{l}\text { African } \\
\text { Eburnean } \\
\text { Pre-Pan- }\end{array}$ & Grant et al., 1972 \\
\hline Kusheriki banded gneiss & $1.2 \& 1.3 \mathrm{Ga}$ & $\mathrm{Rb}-\mathrm{Sr}$ & $\begin{array}{l}\text { African } \\
\text { Eburnean } \\
\text { Pre-Pan- }\end{array}$ & Grant et al., 1972 \\
\hline NW Kaduna migmatite & $1.15 \mathrm{Ga}$ & $\mathrm{Rb}-\mathrm{Sr}$ & $\begin{array}{l}\text { African } \\
\text { Kibaran } \\
\text { Pre-Pan- }\end{array}$ & Grant et al., 1972 \\
\hline
\end{tabular}

Other minerals are plagioclase (about 5\%) occurring as simple twinned crystals. Biotite (about 15\%) occurs as anhedral to subhedral needlike mineral, forming rims around the orthoclase and along the cracks with tiny rounded quartz (Plate I). Accessory minerals include magnetite, illmenite, titanite, zircon and apatite. Medium grained variety revealed that it is composed of quartz (35\%), K-feldspar (30\%), muscovite (15\%), biotite (5\%), plagioclase $(5 \%)$ and iron-oxide (5\%). Quartz occur as fine to medium euhedral and prismatic crystals closely wedge together showing undulose extinction. Orthoclase occurs as cracked phenocryst with quartz inclusions, dense clay minerals and fibrous muscovite. Phenocrysts of quartz and orthoclase looks like an "eye ball" set and stand out from muscovite groundmass. The acicular muscovites surrounding the phenocryst are strongly aligned in the foliation direction and shows blue, purple, yellow and brown interference colours. Biotite occurs as subhedral to euhedral crystals in the groundmass with magnetite and apatite as accessory minerals.

Granite in Mando and Loko border both the gneisses and Birnin Gwari metasediment. The contact zones with the metasediments are sharp with chilled margins as observed west of Mando village stretching for about $1 \mathrm{~km}$. It is a fairly elevated granite outcrop (443m) in places dissected by River Ikanga. This is medium grained granite and observable minerals include pinkish to milky feldspars, silvery muscovite flakes, and black to brownish biotite, in places slightly weathered and brownish green muscovite (Fig. 2). The contact zone with Birnin Gwari staurolite quartz schist extends hundreds of meters and is characterized by granitic dyke intrusion with chilled margins. Two varieties are recognized in the field; the yellowish green and grey types, both containing pink feldspar, biotite and muscovite. Petrographically, quartz $(30 \%)$ occur as subhedral phenocryst together with plagioclase $(5 \%)$, orthoclase (20\%) and microcline $(20 \%)$, as well as medium grain euhedral crystals, closely interlocked with each other and with biotite (10\%) and muscovite (10\%) forming part of the groundmass. K-feldspar occurs as subhedral phenocryst of orthoclase and micro-perthite and as subhedral to euhedral medium grain crystals in the groundmass occurring with microcline and biotite. The orthoclase in few places shows faint albite twinning and sodic feldspars with typical cross hatch twinning and is surrounded by biotite phenocryst. This shows replacement with the evidenced vermicular growth in the K-feldspar (Fig. 2). Both biotite and white mica occur as fibrous and needle-like crystals, align in and squeezing themselves along the foliation plane. Accessory minerals include zircon, magnetite and apatite.

Granite in Nasarawa Kwona area form low lying outcrops, extending southward along Birnin Gwari - Kaduna road for about 2 km, and intersected by river Faleli and tributaries of Kogi Kusheriki. It is a medium grained, pink coloured rock. Macroscopic observation shows the pink feldspar dominating the grey colour quartz; dark colour biotite and muscovite minerals are visible. The dark biotite minerals

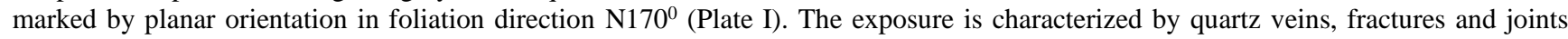
cross cutting one another. The outcrop occurs close to extensive NE trending quartzite outcrop. Microscopically, pink K-feldspar phenocryst is in a fine cloudy quartz and feldspar matrix associated with lesser amount of mafic doted and flakey brown biotite (10\%) and muscovite (5\%) minerals (Fig. 2). Quartz occur as coarse to medium grained subhedral to euhedral prismatic crystals, tightly packed alongside each other, with undulose extinction, constituting $35 \%$ of the matrix. K-feldspar (35\%) is mainly perthitic orthoclase and some tabular microcline with cross hatch, simple and Carlsbad twinning; one half of a simple twinned crystal shows Carlsbad twinning. Some of the K-feldspar and plagioclase crystals show impurities of dense clay minerals and often zoned. Plagioclase minerals are few (5\%) coarse and tabular crystals with albite twinning $\left(\mathrm{An}_{30}\right)$. The doted anhedral biotite minerals fill the interstices of the orthoclase and quartz crystals. Iron-ore occur as assessory euhedral, subhedral to anhedral mineral dotted in the matrix making up 5\% of the rock.

Granite outcrop in Kugu area is a low lying medium grain, weakly foliated rock, showing pink to reddish brown feldspars, grey quartz and dark biotite (Fig. 1). It consists of quartz (25\%), K-feldspar (30\%), plagioclase (25\%), biotite (10\%) and iron-ore (5\%). Euhedral to 
subhedral quartz crystals are welded together and show some fine and dense clay minerals inclusion but still with its characteristics undulose extinction. Plagioclase is euhedral with mica inclusions while biotite occurs as oriented subhedral crystals. Euhedral to subhedral K-feldspars are perthitic, in places masked with faint albite twinning and inclusion of dense mica minerals. Patches of Kfeldspar show vermicular intergrowth with quartz.

Quartzolite is an isolated outcrop northwest of Bagwoma dam. It's a light coloured rock with grey, white, milky and reddish brown contrasting colours and coarse grain fibroblastic texture; with preferred mineral banding $\left(360^{\circ} \mathrm{NS}\right)$ of grey fibrous quartz, light brown to reddish brown biotite and hornblende. The exposure is also characterized by crenulation cleavages and well defined schistocity. Petrographically, the rock consists of quartz (60\%), K-feldspar (10\%), hornblende (15\%), and biotite (10\%) strongly aligned. Quartz is characterized by spherical and polygonal cracks and intergrowth, with acicular biotite sandwiched between it and K-feldspar. Observable alteration is seritization where K-feldspar is altered to an aggregate of finely divided white mica. Hornblende is anhedral, lathlike and elongated with pale brown \& reddish brown crystals (Fig. 2). Biotite occurs as needle-like mineral stacked between the orthoclase polygons. Both hornblende \& biotite are similar in occurrence, but the difference is the better cleavage in hornblende. Accessory minerals are opaque minerals as inclusions in the hornblende and plagioclase.

Porphyritic biotite granite in Gwaska occur as porphyritic leucosome that intruded the Gwaska paleosome, comprising mainly felsic minerals such as quartz (40\%) and K-feldspar (40\%), with biotite (15\%) as ferromagnesian mineral. Quartz occurs as euhedral to subhedral medium crystals in between the feldspars and is characterized by myrmekitic intergrowth with orthoclase. K-feldspar subsolvus consisting of orthoclase (perthitic and micro-perthitic) and microcline with cross hatch twinning. The feldspars also contain dense mass of clay and mica minerals as alterations. Biotite crystals are anhedral, scattered in the matrix and along cracks in between the feldspars and enclosed in the orthoclase. Accessory minerals include apatite and magnetite.

\subsubsection{Granite gneisses}

The granite and migmatitic gneisses occur as prominent outcrops and as low lying whale back exposures along river channels in Kampani Doka and Kungwi areas respectively.

Kampani Doka granitic gneisses occur as prominent outcrop (about 520m high) is fine grained, weakly foliated equigrannular pink to reddish brown rock, being quarried for constructional material. Microscopically, it consists of quartz (30\%), orthoclase (25\%) muscovite $(25 \%)$, iron-oxide (10\%) and biotite (5\%). Quartz forms clusters of polygonal and prismatic crystal intergrowth, and as groundmass with K-feldspars, muscovite iron-oxide and biotite. Muscovite minerals are anhedral but aligned along-side quartz intergrowth. Iron-oxide formed part of the groundmass and medium grain sizes clustered with and sometimes encircling the quartz crystals. Biotite also occurs as accessory along-side the doted iron-oxide. The low lying highly foliated Kampani Doka outcrop is found along the tributaries of Kusheriki river channel. In thin section the rock is composed of phenocryst of quartz (30\%), K-feldspar (25\%) biotite (25\%) epidote $(10 \%)$ and iron-ore $(5 \%)$ set in groundmass comprising polygonal quartz, feldspar, biotite and iron-ore. Biotite occurs as platy elongated subhedral crystals dotted between the polygonal intergrowths of quartz crystals. Accessory minerals include zircon, apatite, titanite and magnetite.

\subsection{Geochemistry}

\subsubsection{Rock classification}

The rocks plot in the field of granite and granodiorites and quartzolite as on the nomenclature of (after Middlemost, 1979) (Fig. 4A and B) and show sub-alkaline affinity in agreement with petrographic characteristics (Fig. 4). The normative Ab-An-Or Feldspar triangle of O'Connor (1965) diagram also shows the rocks plot in granite and granodiorite field; here, granites and weakly foliated biotite granite gneiss (BGn10) straddle between granite and granodiorite field (Fig. 4B). The granodiorite may have resulted from close relationships with and reaction
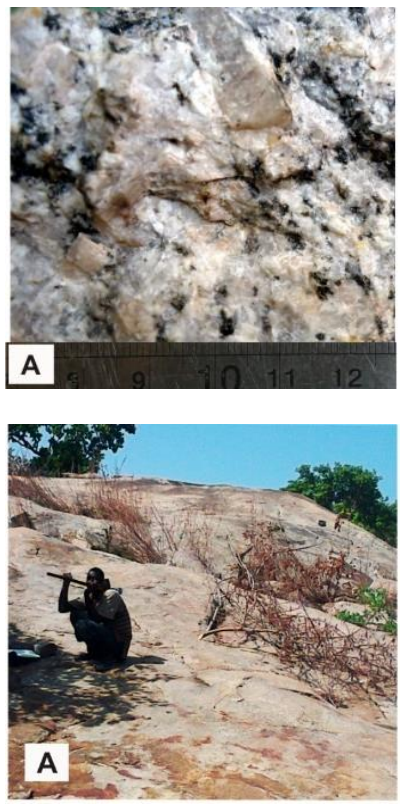
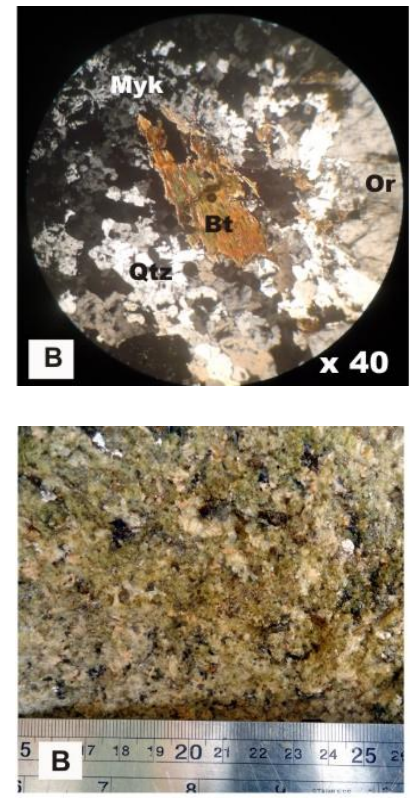
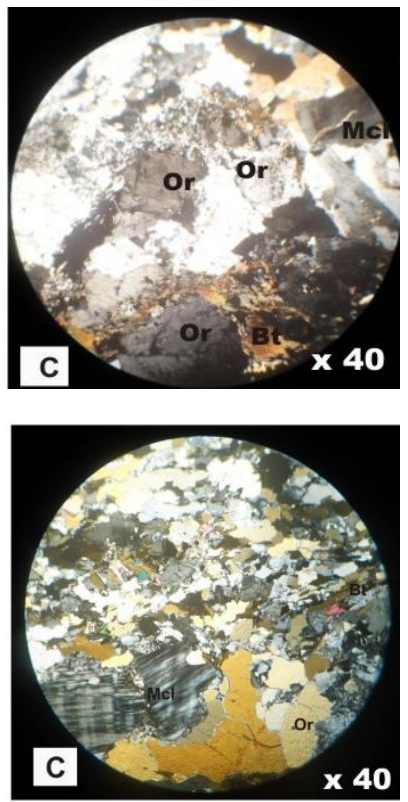

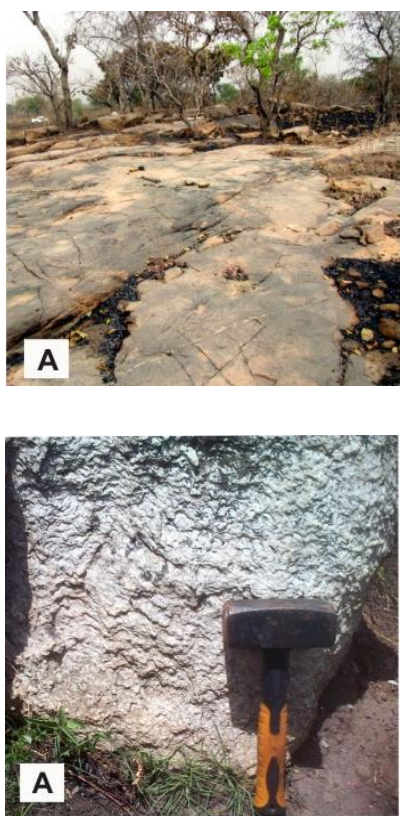
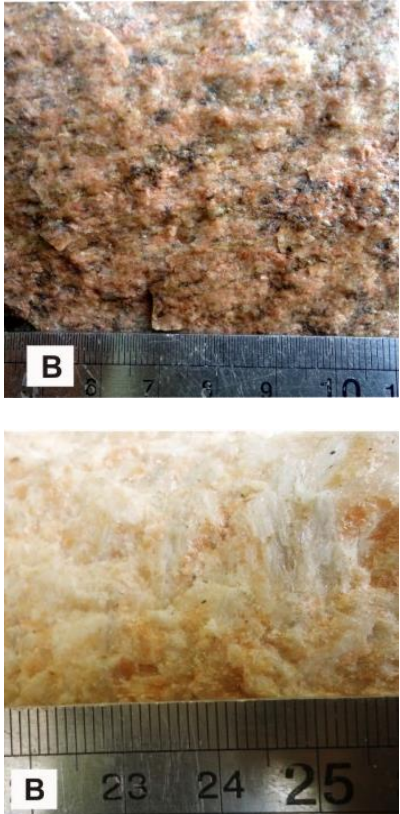
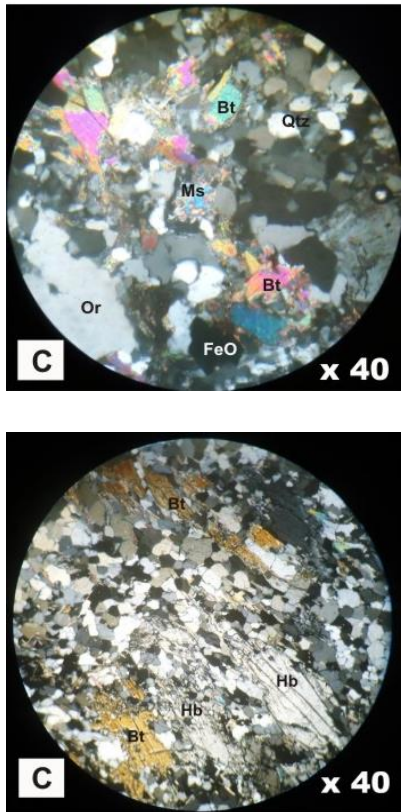

Fig. 2: Outcrops, Hand Specimen and Photomicrograph of Gworon Dutse Biotite Granite; Mando Biotite-Muscovite Granite; Nassarawa Kwona BiotiteWhite Mica Granite and Bagwoma Quartzolite in the Birnin Gwari Schist Belt.

Table 2: Modal Composition of Granite in the Birnin Gwari Schist Belt

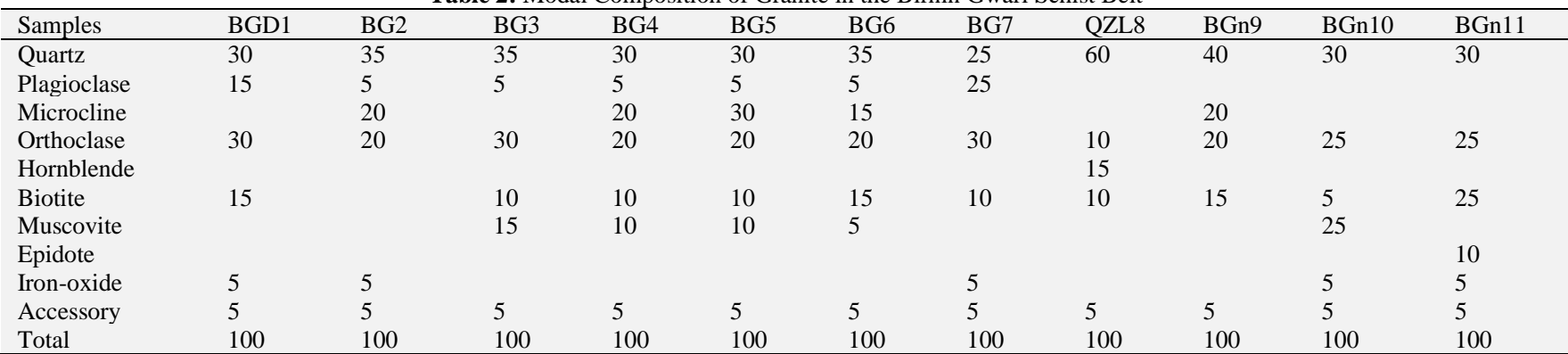

LEGEND: BGD1=Birnin Gwari/Mando Biotite Granodiorite. BG2=Goron Dutse coarse porphyritic biotite granite. BG3= Goron Dutse medium grained biotite-muscovite granite. BG4=Mando biotite-muscovite granite. BG5= Mando/Loko biotite-muscovite granite. BG6=Nassarawa Kwona biotite-muscovite granite. BG7=Kugu Biotite Granite. BG8=Bagwoma quartzolite. BG9=Gwaska leucosome (Biotite Granite). BGn10= Kampani Doka biotite-muscovite granite gneiss. BGn11=Kampani Doka biotite granite gneiss. BGn12=Kungwi migmatitic gneiss.

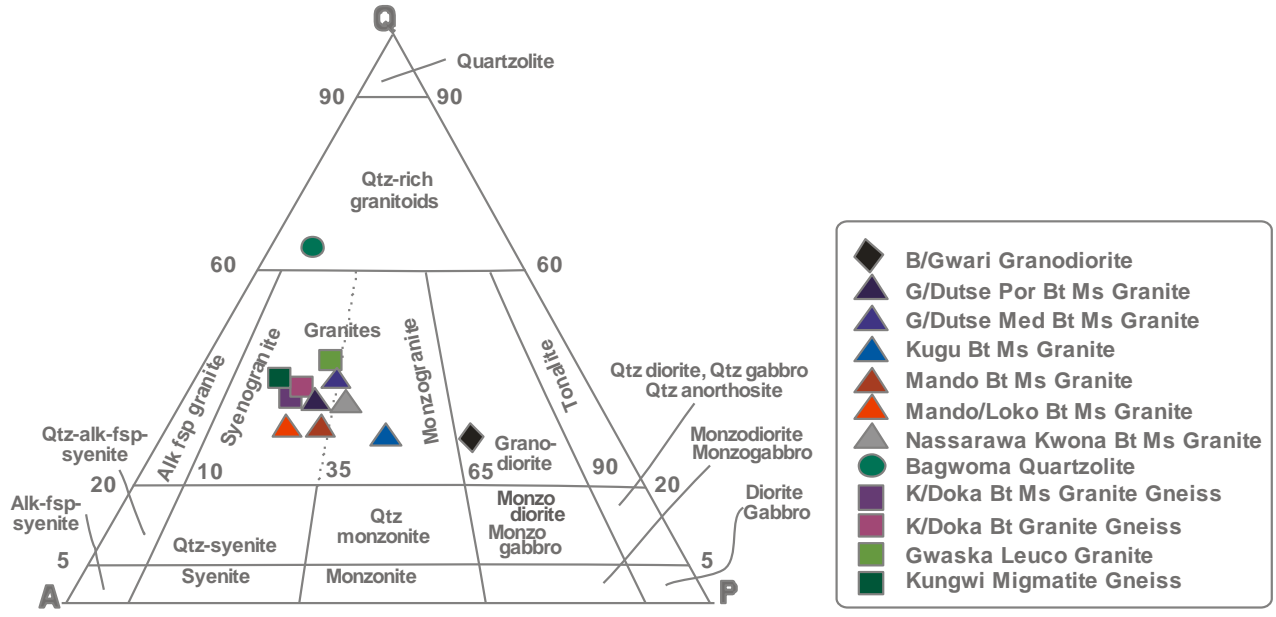

Fig. 3: Modal Classification Diagrams of the Granite in the Birnin Gwari Schist Belt (After Streckeisen, 1976).

between Birnin Gwari schist and Mando biotite-white mica granite, a phenomenon that may be attributed to the mobility of Na and $\mathrm{K}$ during hydrothermal alteration (Fig. 1).

\subsubsection{Major element characteristics}

Birnin Gwari Granitoids exhibits wide range of silica contents $(65.24-82.42 \mathrm{wt} \%)$; granodiorite (65.24 wt \%), granite $(70.15-76.73$ wt $\%$ ) and quartzolite (82.42 wt \%). Granites are generally depleted in $\mathrm{TiO}_{2}(0.2$ to $0.41 \%), \mathrm{Fe}_{2} \mathrm{O}_{3}(0.36$ to $2.41 \%), \mathrm{MgO}(0.1$ to 0.86 $\%)$ and $\mathrm{CaO}(0.04$ to $1.94 \%)$ compared to granodiorites with $\mathrm{TiO}_{2}(0.82 \%), \mathrm{Fe}_{2} \mathrm{O}_{3}(5.13 \%), \mathrm{MgO}(2.31 \%)$ and $\mathrm{CaO}(3.06 \%)(\mathrm{Table}$ 
3). The major element composition of the granites, granodiorite and quartzolite as well as granite gneiss plotted on Harker diagram using $\mathrm{SiO}_{2}$ as an index of differentiation show that $\mathrm{TiO}_{2}, \mathrm{Fe}_{2} \mathrm{O}_{3}, \mathrm{MgO}, \mathrm{CaO}$ and $\mathrm{P}_{2} \mathrm{O}_{5}$ are all negatively correlated with $\mathrm{SiO}_{2}$, generally forming a well-defined linear trend. $\mathrm{Al}_{2} \mathrm{O}_{3}$ content on the average is high in granodiorite, granite and quartzolite $(12.86-15.99 \mathrm{wt} \%)$. $\mathrm{Al}_{2} \mathrm{O}_{3}$ and $\mathrm{Na}_{2} \mathrm{O}$ shows
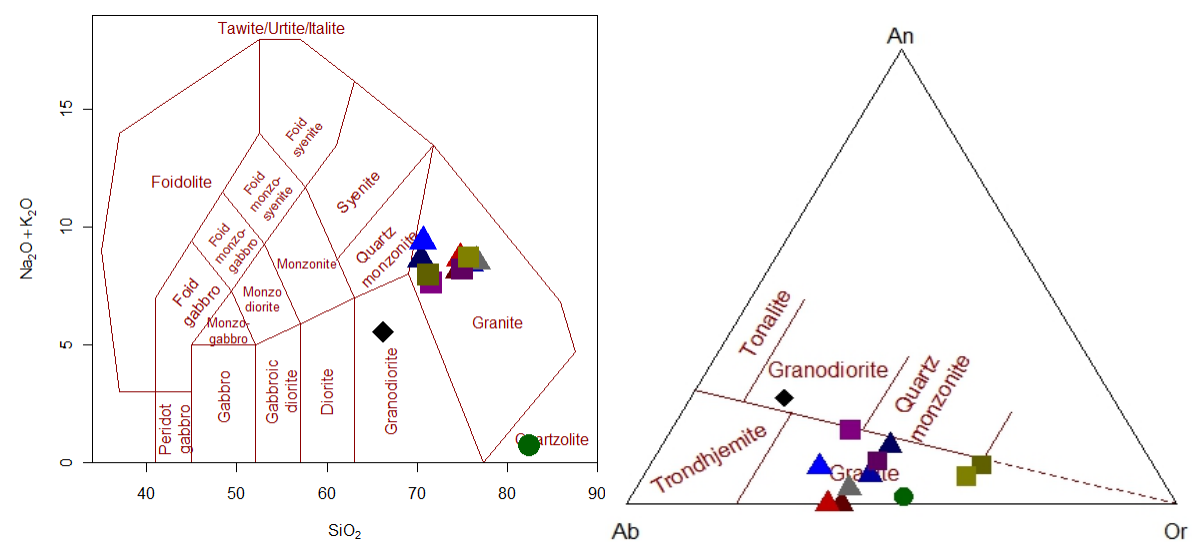

Fig. 4: (A): (A) $\mathrm{SiO}_{2} \mathrm{Vs} \mathrm{Na}_{2} \mathrm{O}+\mathrm{K}_{2} \mathrm{O}$ Versus Diagram (Middlemost, 1985) With Nomenclature of the Granite As Granites, Grandorites and Quartzolite, Distinguishing Them As Subalkaline Magmatic Series (After Cox et al., 1979) and (B) Normative An-Ab-Or Diagram Showing the Distribution of the Rocks in Granitic to Granodioritic Field (After O'Connor, 1965) of Granite in the Northern Part of Birnin Gwari Schist Belt (Symbols As in Fig. 3).
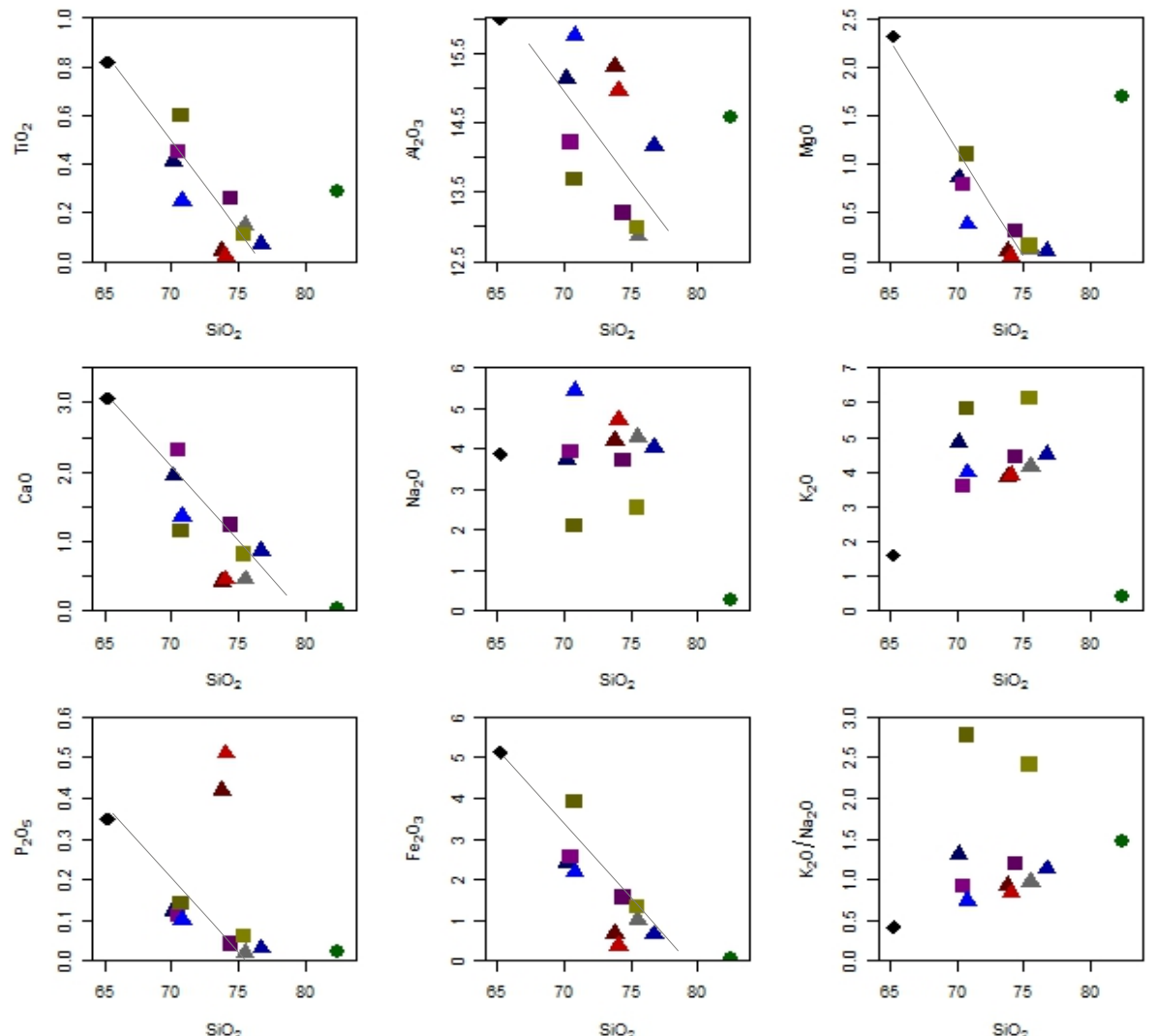

Fig. 5: Harker Variation Diagrams; Silica $\left(\mathrm{SiO}_{2}\right.$ Wt \%) Plotted Against a Range of Major (in Wt \%) Elements in the Granite of Birnin Gwari Schist Belt (Symbols as in Fig. 3).

Table 3: Major Elements (in Wt \%) Abundance of Granite and the Host (Granite Gneiss) in the Northern Part of Birnin Gwari Schist Belt

\begin{tabular}{|c|c|c|c|c|c|c|c|c|c|c|c|c|}
\hline $\begin{array}{l}\text { Sample } \\
\text { Name }\end{array}$ & $\begin{array}{l}\text { BGD1 } \\
\text { G/diorite }\end{array}$ & $\begin{array}{l}\text { BG2 } \\
\text { Granite }\end{array}$ & BG3 & BG4 & BG5 & BG6 & BG7 & $\begin{array}{l}\text { KQZL8 } \\
\text { Quartzolite }\end{array}$ & $\begin{array}{l}\text { BGN9 } \\
\text { Host C }\end{array}$ & $\begin{array}{l}\text { BGN10 } \\
\text { ite Geiss }\end{array}$ & BGN11 & BGN12 \\
\hline $\mathrm{SiO}_{2}$ & 65.24 & 70.15 & 76.73 & 73.76 & 74.06 & 75.5 & 70.79 & 82.42 & 75.44 & 74.42 & 70.49 & 70.74 \\
\hline $\mathrm{TiO}_{2}$ & 0.82 & 0.41 & 0.07 & 0.04 & 0.02 & 0.15 & 0.25 & 0.29 & 0.11 & 0.26 & 0.45 & 0.6 \\
\hline $\mathrm{Al}_{2} \mathrm{O}_{3}$ & 15.99 & 15.12 & 14.16 & 15.3 & 14.95 & 12.86 & 15.74 & 14.57 & 12.99 & 13.2 & 14.21 & 13.68 \\
\hline $\mathrm{Fe}_{2} \mathrm{O}_{3}$ & 5.13 & 2.41 & 0.64 & 0.66 & 0.36 & 0.99 & 2.17 & 0.03 & 1.32 & 1.55 & 2.55 & 3.91 \\
\hline $\mathrm{MnO}$ & 0.07 & 0.04 & 0.01 & 0.03 & 0.06 & 0.08 & 0.04 & 0.17 & 0.03 & 0.05 & 0.09 & 0.04 \\
\hline $\mathrm{MgO}$ & 2.31 & 0.86 & 0.1 & 0.11 & 0.06 & 0.13 & 0.38 & 1.7 & 0.16 & 0.31 & 0.79 & 1.1 \\
\hline $\mathrm{CaO}$ & 3.06 & 1.94 & 0.87 & 0.41 & 0.45 & 0.45 & 1.35 & 0.04 & 0.82 & 1.24 & 2.31 & 1.15 \\
\hline $\mathrm{K}_{2} \mathrm{O}$ & 1.6 & 4.86 & 4.52 & 3.87 & 3.89 & 4.14 & 3.98 & 0.41 & 6.13 & 4.42 & 3.6 & 5.81 \\
\hline $\mathrm{P}_{2} \mathrm{O}_{5}$ & 0.35 & 0.12 & 0.03 & 0.42 & 0.51 & 0.02 & 0.1 & 0.02 & 0.06 & 0.04 & 0.11 & 0.14 \\
\hline LOI & 1.09 & 0.35 & 0.42 & 0.97 & 0.7 & 0.51 & 0.46 & 0.57 & 0.27 & 1.01 & 0.59 & 0.56 \\
\hline Total & 99.53 & 99.98 & 101.5 & 99.77 & 99.76 & 99.12 & 100.6 & 100.5 & 99.87 & 100.21 & 100.21 & 99.82 \\
\hline $\mathrm{K}_{2} \mathrm{O} / \mathrm{Na}_{2} \mathrm{O}$ & 0.41 & 1.30 & 1.12 & 0.92 & 0.82 & 0.96 & 0.73 & 1.46 & 2.41 & 1.19 & 0.91 & 2.77 \\
\hline Fe-number & 0.68 & 0.73 & 0.98 & 0.85 & 0.85 & 0.88 & 0.85 & 0.01 & 0.89 & 0.83 & 0.76 & 0.78 \\
\hline
\end{tabular}


Table 4: Trace Elements (in Ppm) Abundance of Granite and the Host (Granite Gneiss) in the Northern Part of Birnin Gwari Schist Belt

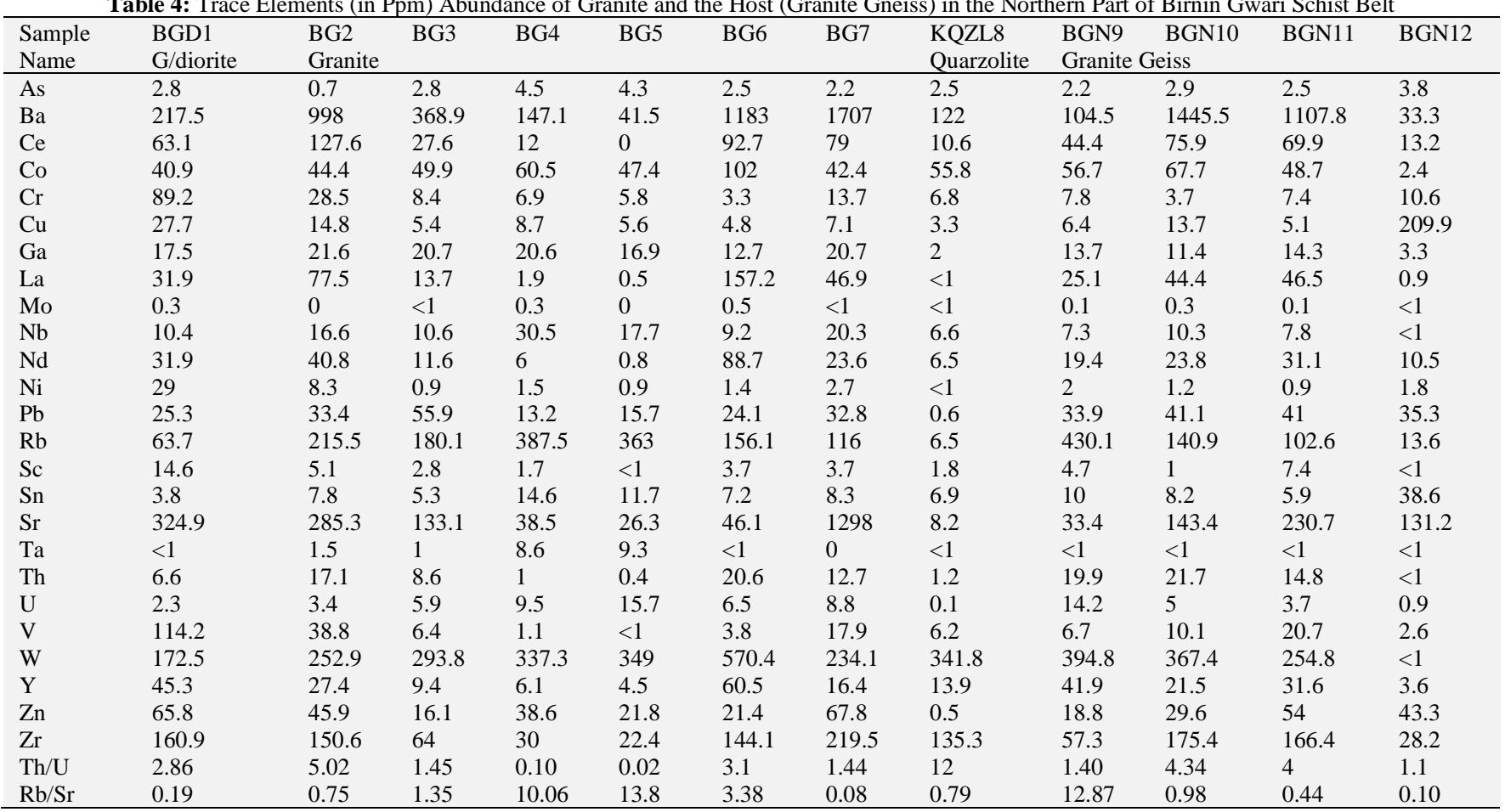

negative correlation but with scattered trend, while $\mathrm{K}_{2} \mathrm{O}$ shows positive correlation (Table 2; Fig. 5). The contents of Na $2 \mathrm{O}$ ( 3.72 - 4.29 wt $\%)$ and $\mathrm{K}_{2} \mathrm{O}(4.14-4.86 \mathrm{wt} \%)$ is high in granite except for granodiorite and quartzolite. $\mathrm{K}_{2} \mathrm{O} / \mathrm{Na}_{2} \mathrm{O}$ ratio in granite is $0.41-1.30$.

\subsubsection{Trace element characteristics}

The trace elements of the granitoids plotted on Harker diagram using $\mathrm{SiO}_{2}$ as an index of differentiation show that $\mathrm{Ba}, \mathrm{Ce}, \mathrm{Cr}, \mathrm{La}, \mathrm{Sr}, \mathrm{Zr}$ and $\mathrm{Nb}$ are negatively correlated with $\mathrm{SiO}_{2}$ generally forming a well-defined linear trend while $\mathrm{Rb}, \mathrm{U}$, Th and $\mathrm{Y}$ are all negatively correlated, with slightly scattered trend (Fig. 6). The trace elements composition and ratios are presented in Table 4 and primitive mantlenormalized elements contents spider diagrams after Sun and McDonough (1989) are shown in Fig. 7. The normalized abundance patterns permit characterization of the rocks. Granites, granodiorite, quartzolite and granite gneisses show similar spider distribution patterns, but with some deviation; an implication of close genetic relationship but different source materials. Some samples of granite (BG2 and BG3) and granitic gneisses (BGn10 and BGn11) show enrichment of the large ion lithophile elements (LILE: Ba, Rb, K; radioelements Th and $\mathrm{U}$ and depletion of the high field strength elements (HFSE: Nb, Ce, P and Ti), while granodiorite (BGD1), granite (BG3, BG4 and BG5) and granitic gneiss samples (BGn9 and BGn12) are depleted in $\mathrm{Rb}, \mathrm{Ba}$ and $\mathrm{La}$ (Fig. 6). Rb is fairly enriched in the granites (116 - 215.5 $\mathrm{ppm})$ and granite gneiss $(102-430 \mathrm{ppm})$, slightly depleted in granodiorite $(63.7 \mathrm{ppm})$ and completely depleted in quartzolite $(6.5 \mathrm{ppm})$ compared to the mean crustal average of $90 \mathrm{ppm}$. Ba content is variable in the rocks; varies in granite (as low as 41.5 and as high as 1707 $\mathrm{ppm})$, granodiorites $(217.5 \mathrm{ppm})$ and very high in granite gneiss $(104.5-1107.8 \mathrm{ppm})$. Sr varies in granite $(26.3-1298 \mathrm{ppm})$, and granite gneiss $(33.4-230.7 \mathrm{ppm})$ and moderately high in granodiorite $(324.9 \mathrm{ppm})$, showing negative correlation with increasing $\mathrm{SiO}_{2}$; consistent with small plagioclase abundances of this rocks. The ratio $\mathrm{Th} / \mathrm{U}$ is $0.02-1.45$ in granite (exceptions are samples BG2 and BG7 with 5.02 and 12 respectively); 1.1 - 1.4 in granite gneiss (exceptions are samples BGn10 and BGn11 with 4.34 and 4 respectively); and 2.86 in granodiorite. 

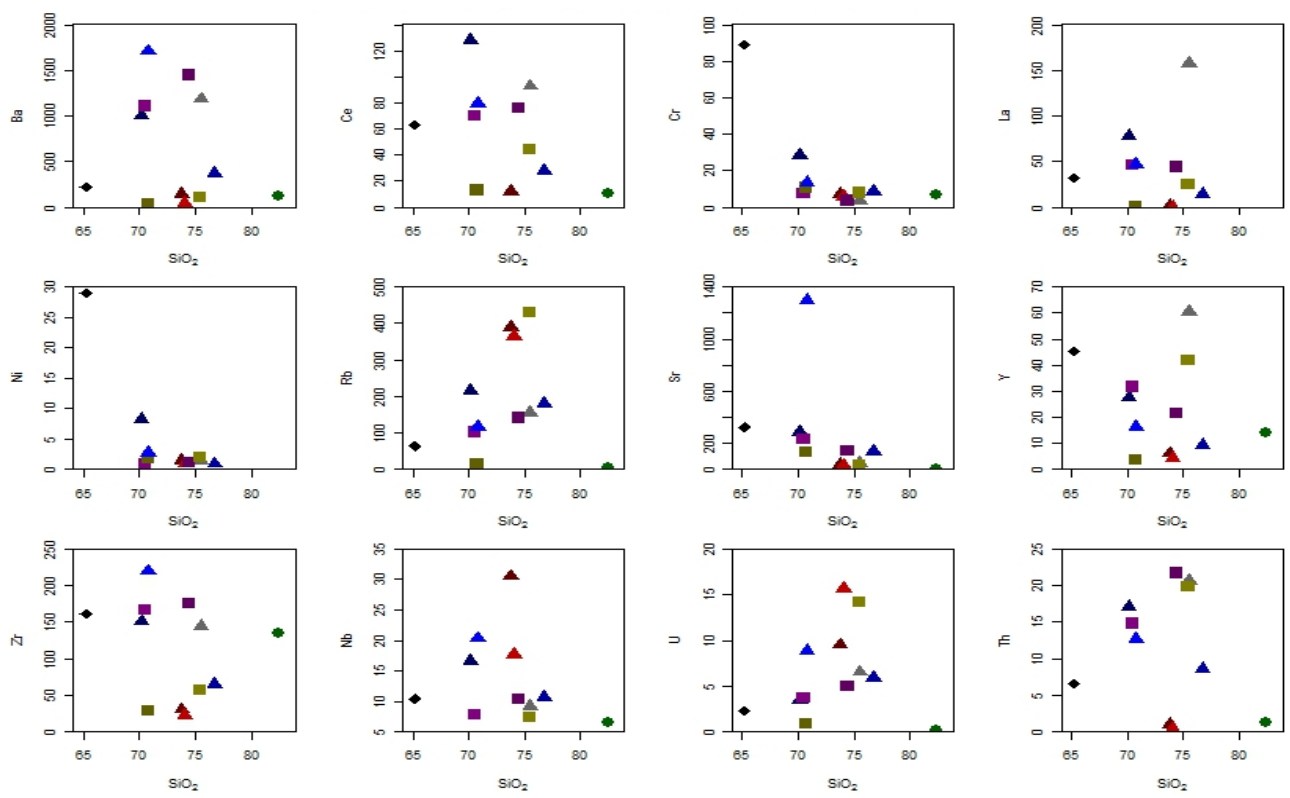

Fig. 6: Harker Variation Diagrams; Silica $\left(\mathrm{SiO}_{2} \mathrm{Wt} \%\right)$ Plotted Against A Range of Trace (in Ppm) Elements in the Granite of Birnin Gwari Schist Belt (Symbols As in Fig. 3).

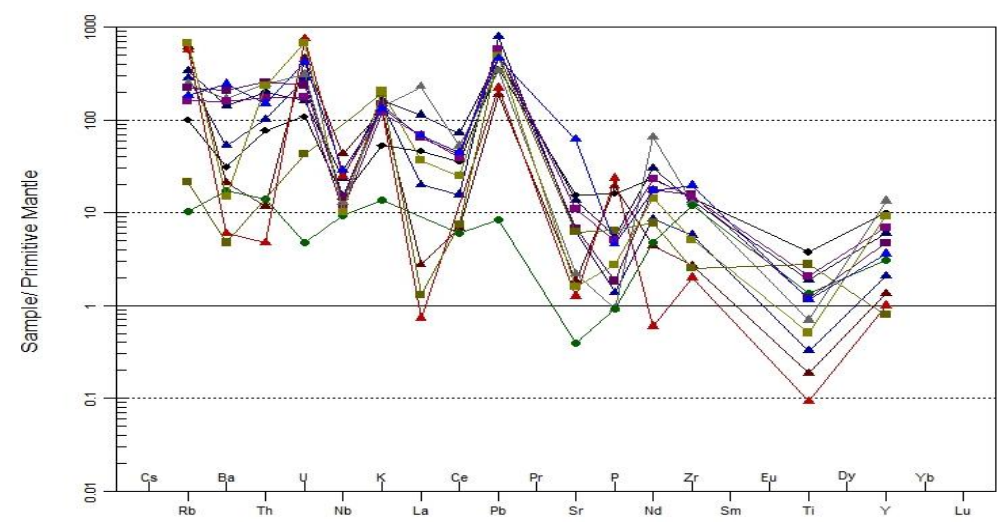

Fig. 7: Mantle-Normalized Multi-Element Diagram of Granite in the Northern Part of Birnin Gwari Schist Belt (Sun and Mcdonough, 1989) (Symbols as in Fig. 3).

\subsubsection{Rare earth elements characteristics}

Chondrite-normalized REE patterns (Boynton, 1984) are presented in Table 5 and Fig. 8. The Birnin Gwari granite show a Light Rare Earth Elements (LREE) enrichment relatively to Heavy Rare Earth Elements (HREE), low to high fractionation $[(\mathrm{La} / \mathrm{Yb}) \mathrm{N}=6.74-$ 45.14] with pronounced negative Eu anomaly with Eu/Eu* values between $0.38-0.62$. Granite sample (BG4) however exhibit near flat LREE and HREE trend with slight negative Eu anomaly (0.38).

Table 5: REE Data (Ppm) on the Granite in the Northern Part of Birnin Gwari Schist Belt

\begin{tabular}{|c|c|c|}
\hline Sample & BG 2 & BG 4 \\
\hline $\mathrm{La}$ & 61.6 & 2.9 \\
\hline $\mathrm{Ce}$ & 111.15 & 5.87 \\
\hline $\mathrm{Pr}$ & 12.17 & 0.79 \\
\hline $\mathrm{Nd}$ & 38.4 & 2.8 \\
\hline $\mathrm{Sm}$ & 5.83 & 0.78 \\
\hline $\mathrm{Eu}$ & 0.64 & 0.16 \\
\hline $\mathrm{Gd}$ & 4.49 & 0.80 \\
\hline $\mathrm{Tb}$ & 0.54 & 0.14 \\
\hline Ho & 0.49 & 0.13 \\
\hline Er & 1.25 & 0.33 \\
\hline Tm & 0.17 & 0.05 \\
\hline $\mathrm{Yb}$ & 0.92 & 0.29 \\
\hline $\mathrm{Lu}$ & 0.12 & 0.04 \\
\hline$\sum \mathrm{REE}$ & 240.56 & 15.90 \\
\hline$(\mathrm{La} / \mathrm{Yb})_{\mathrm{N}}$ & 45.14 & 6.74 \\
\hline$(\mathrm{Ce} / \mathrm{Yb})_{\mathrm{N}}$ & 31.25 & 5.24 \\
\hline$(\mathrm{Ce} / \mathrm{Sm})_{\mathrm{N}}$ & 4.60 & 1.82 \\
\hline$(\mathrm{Eu} / \mathrm{Yb})_{\mathrm{N}}$ & 1.98 & 1.57 \\
\hline $\mathrm{Eu} / \mathrm{Eu}^{*}$ & 0.38 & 0.62 \\
\hline
\end{tabular}




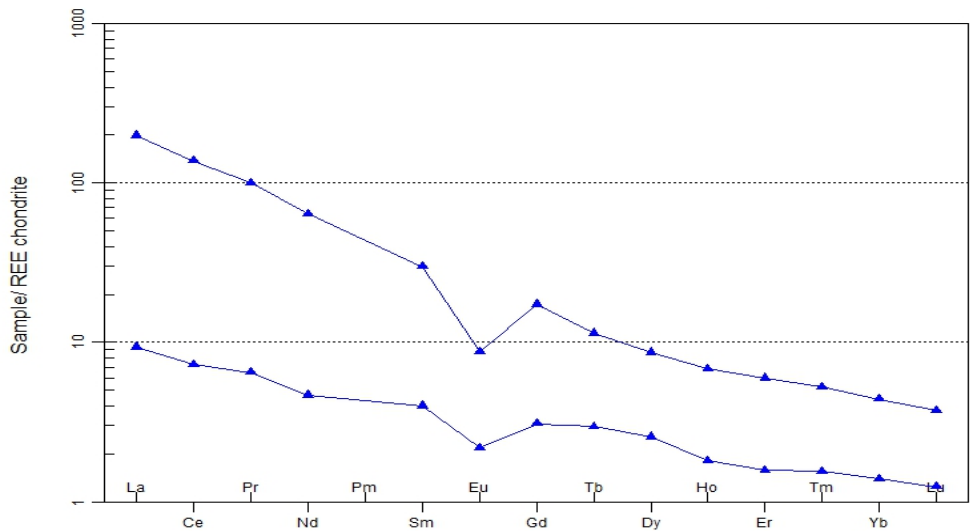

Fig. 8: Chondrite-Normalized Pattern for the Birnin Gwari Schist Belts Granite, Chondrite Normalization Values are from (Boynton, 1984) (Symbols as in Fig. 3).

\subsubsection{Magma characterization}

The magma types are illustrated by the AFM diagram of Irvine and Baragar (1971) and show calc-alkaline affinity with granite, granodiorite, quartzolite and the host granite gneiss clustering in the calc-alkaline field (Fig. 9). $\mathrm{The}_{\mathrm{SiO}_{2}} \mathrm{vs} \mathrm{Fe}_{2} \mathrm{O}_{3} /\left(\mathrm{Fe}_{2} \mathrm{O}_{3}+\mathrm{MgO}\right) ; \mathrm{SiO}_{2}$ vs $\mathrm{Na}_{2} \mathrm{O}+\mathrm{K}_{2} \mathrm{O}-\mathrm{CaO}$ and ASI vs A/NK diagram (after Frost et al, 2001) distinguish Birnin Gwari granite as magnesian with ferroan character, calc-calcic to alkali calcic and peraluminous (Fig. 10). The granites with higher Fe-number (0.73 - 0.89) are generally ferroan while the grandiorites and granite gneisses with low Fe-number $(<0.76)$ are magnesian (Table 4; Fig. 10A). The granites and granodiorites can be further classified into calc-alkalic - alkali-calcic and on the Modified Alkali-Lime Index (MALI) plot of Na2O+ $\mathrm{K}_{2} \mathrm{O}-\mathrm{CaO}$ versus $\mathrm{SiO}_{2}$ discrimination diagram (Frost et al., 2001) (Fig. 10B). The granites and granodiorites are peraluminous with the Al saturation index (ASI) ranging from 1.0 to 1.5. However, the Kampani Doka biotite and biotite-muscovite gneiss (BGn10 and BGn11) and the Kugu biotite granite (BG7) straddle between peraluminous and metaluminous (Fig. 10C). The alkali concentration discrimination diagram $\mathrm{K}_{2} \mathrm{O}$ vs $\mathrm{Na}_{2} \mathrm{O}$ in wt $\%$ and $\mathrm{SiO}_{2}$ vs $\mathrm{K}_{2} \mathrm{O}$ of Peccerillo and Taylor (1976) define granites as I-type and of high-K calc-alkaline; granodiorites as calc-alkaline and granite gneiss as shoshonite series, the exceptions being the S-type Gwaska leuco granite (BG10) and the Kungwi migmatite gneiss (BGn12) (Figs. 1 \& 11A and B). Using the series of diagrams that employ $\mathrm{Ga} / \mathrm{Al}$ and $\mathrm{Y}, \mathrm{Ce}, \mathrm{Nb}$ and $\mathrm{Zr}$ against various major elements ratios and $\mathrm{Zn}, \mathrm{Zr}$ and $\mathrm{Y}$, designed by Whalen et al., (1987) to discriminate A-type granites from I- and Stypes (Fig. 12), granite in the Birnin Gwari schist belt plot in the field of I- and S- type or close to the boundary of the A-type granite. On the $\mathrm{Sr}-\mathrm{Rb}$-Ba ternary diagram after Tarney and Jones (1994) (Fig. 13A), the granitoids shows diverse trend towards high and low Ba-Sr as well as adakite granitoids. The Ba-Rb-Sr ternary diagram (after El Bouseily and El Sokkary, 1975) also shows wide distribution of the granites as "granodiorite and quartz diorite", "anomalous", "normal" and "strongly differentiated"; granodiorite as "diorite" and quartzolite as "normal" granite (Fig. 13B).

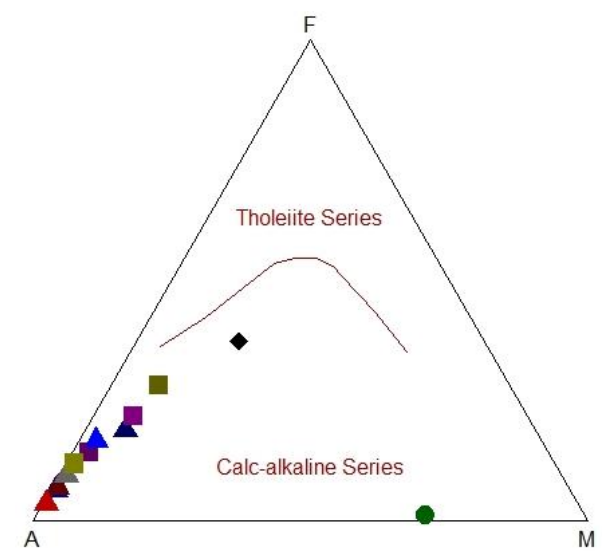

Fig. 9: AFM Diagram (After Irvine and Baragar, 1971) Discriminating Birnin Gwari Granite as Calc-Alkaline Series (Symbols as in Fig. 3).
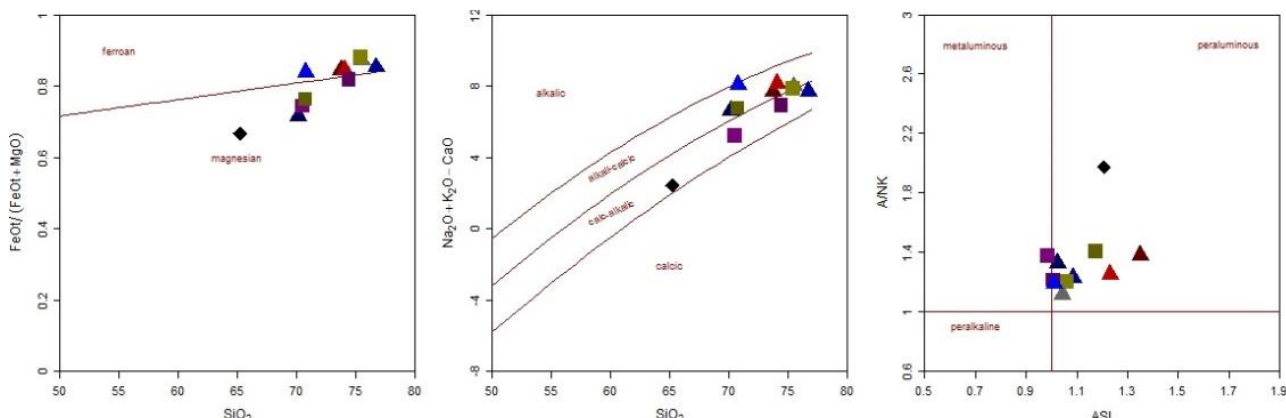

Fig. 10: (A) $\mathrm{SiO}_{2} \mathrm{Vs} \mathrm{Fe}_{2} \mathrm{O}_{3} /\left(\mathrm{Fe} 2 \mathrm{O} 3+\mathrm{Mgo}\right.$ ); (B) $\mathrm{Sio}_{2} \mathrm{Vs} \mathrm{Na}_{2} \mathrm{O}+\mathrm{K}_{2} \mathrm{O}-\mathrm{Cao}$ and (C) ASI vs. A/NK Diagram (After Frost et al, 2001) Discriminating the Birnin Gwari Granite as Mainly Magnesian, Alkali-Calcic to Alkali and Metaluminous (Symbols as in Fig. 3). 

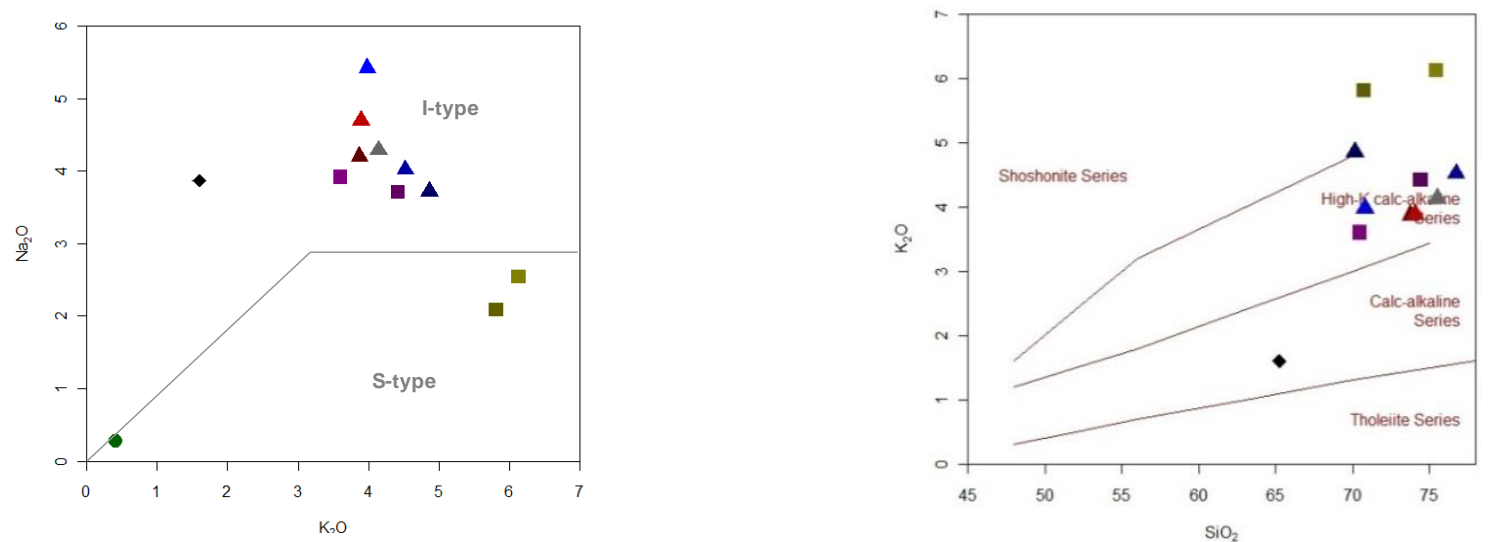

Fig. 11: (A) Alkali Concentration Discrimination Diagram $\left(\mathrm{K}_{2} \mathrm{O}\right.$ Vs Na $2 \mathrm{O}$ in Wt \%) Defining the I-Type Nature of the $\mathrm{Granite} \mathrm{And}(\mathrm{B}) \mathrm{SiO}_{2}$ vs. $\mathrm{K}_{2} \mathrm{O}$ After Peccerillo and Taylor (1976) Discriminating Granite as Calc-Alkaline, High-K Calc-Alkaline and Shoshonite Series in the Northern Part of the Birnin Gwari Schist Belt (Symbols as in Fig. 3).

\subsubsection{Geotectonic setting}

On the multicratonic R1-R2 diagram of Batchelor and Bowden (1985), the granite is dominantly of syn-collisional type (Fig. 14A). Also the $\mathrm{Zr}$ vs (Nb/Zr) N diagram of Thiéblemont and Tegyey (1994) with normalization values from Sun and McDonough (1989) delineate the tectonic setting of the granite as subduction-zone magmatic rocks (Fig. 14B). The $\mathrm{Y}+\mathrm{Nb}$ vs $\mathrm{Rb}$ and $\mathrm{Y}$ vs $\mathrm{Nb}$ geotectonic discrimination diagram (after Pearce et al., 1984) shows granite plot in the volcanic arc and syn-collision granitoid fields (Fig. 15). The $\mathrm{SiO}_{2}$ vs $\mathrm{K}_{2} \mathrm{O} ; \mathrm{SiO}_{2}$ vs $\mathrm{Fe}_{2} \mathrm{O}_{3} /\left(\mathrm{Fe}_{2} \mathrm{O}_{3}+\mathrm{MgO}\right), \mathrm{M} / \mathrm{AFM}$ vs F/AFM and C/ACF vs F/ACF tectonic discrimination diagram of Maniar and Piccolli, (1989), plotted in fields of island arc (IAG), continental arc granite (CAG) and continental collision granite (CCG) (Fig. 16).
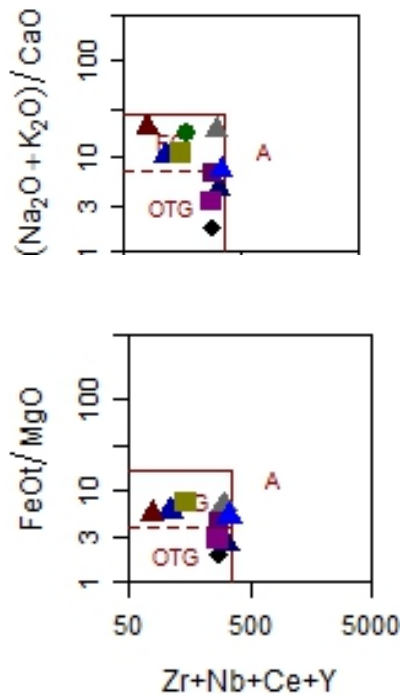
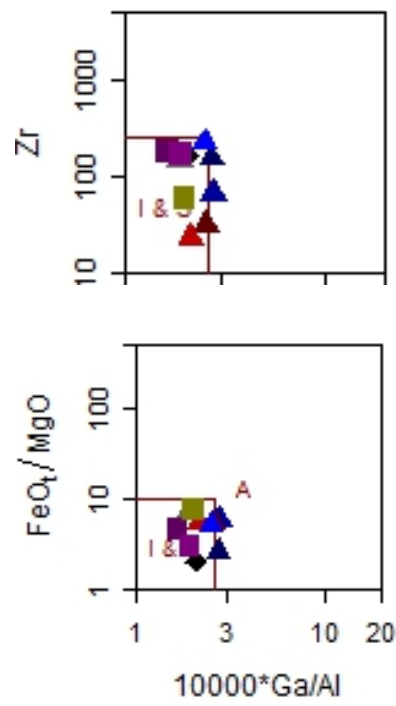
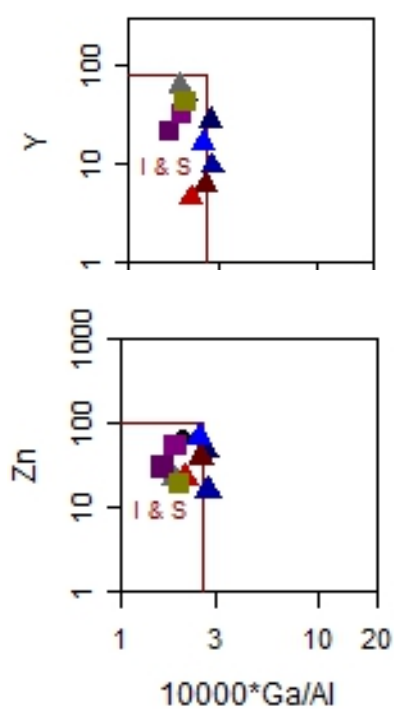

Fig. 12: Set of Binary Plots $\mathrm{Zr}+\mathrm{Nb}+\mathrm{Ce}+\mathrm{Y}$ vs. $\mathrm{Fe}_{2} \mathrm{O}_{3} / \mathrm{Mgo}$ and $\left(\mathrm{Na}_{2} \mathrm{O}+\mathrm{K}_{2} \mathrm{O}\right) / \mathrm{Cao} ; 10000 * \mathrm{Ga} / \mathrm{Al}$ vs. $\mathrm{Fe}_{2} \mathrm{O}_{3} / \mathrm{Mgo}$ and $\mathrm{K}_{2} \mathrm{O}+\mathrm{Mgo} ; 10000 * \mathrm{Ga} / \mathrm{Al}$ vs. $\mathrm{Y}$ and Ce Proposed by (Whalen et al., 1987) to Distinguish A-Type Granite From I- and S-Type (Major Elements in Wt \% and Trace Elements and REE in Ppm) (Symbols as in Fig. 3).
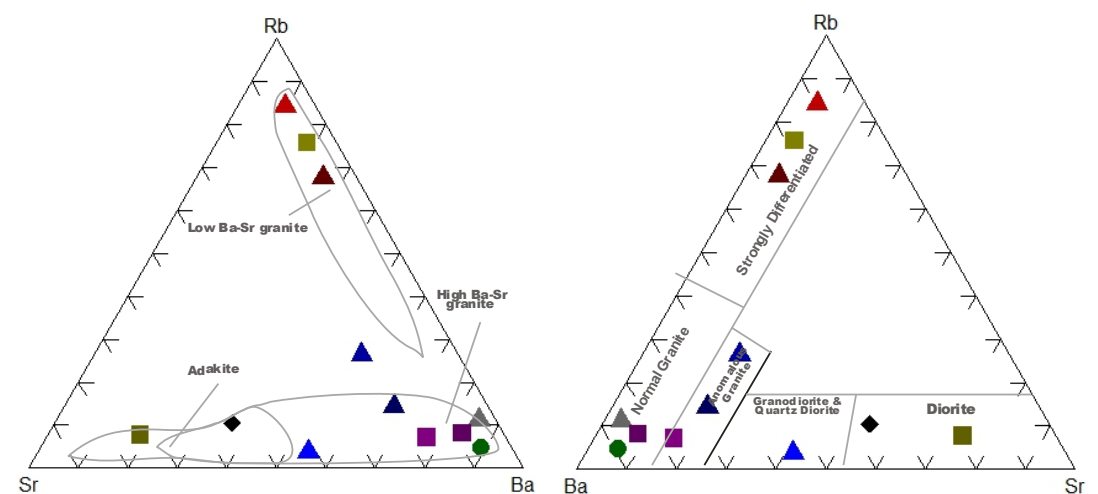

Fig. 13: Sr-Rb-Ba Ternary Diagram After Tarney and Jones (1994) Illustrating the High Ba-Sr Nature and Ba-Rb-Sr Ternary Diagram Showing the Distribution of the Granites and the Granodiorite (After El Bouseily and El Sokkary, 1975) of the Birnin Gwari Schist Belt Granite (Symbols as in Fig. 3). 

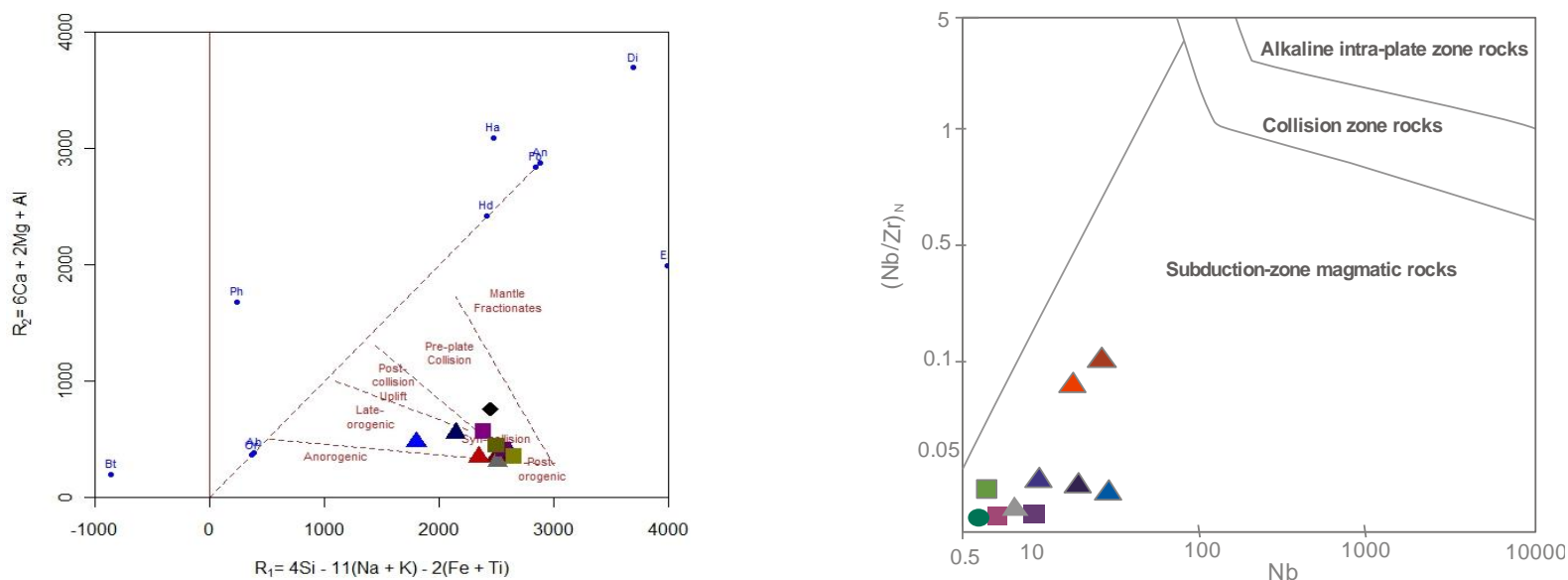

Fig. 14: $R 1$ vs. $R 2$ Diagram of (Batchelor and Bowden, 1985) $\left[R_{1}=\left(4 \mathrm{Si}-11(\mathrm{Na}+\mathrm{K})-2(\mathrm{Fe}+\mathrm{Ti}) ; \mathrm{R}_{2}=(6 \mathrm{Ca}+2 \mathrm{Mg})+\mathrm{Al}\right)\right]$. and $\mathrm{Nb}$ vs. $(\mathrm{Nb} / \mathrm{Zr})_{\mathrm{N}} \mathrm{Diagram}$ of Thiéblemont and Tegyey (1994) [(in the Subduction-Zone Magmatic Rocks, Normalization Values from Sun and Mcdonough (1989)] to Delineate the Tectonic Setting of the Granite in the Northern Birnin Gwari Schist Belt. (Symbol as in Fig. 3)
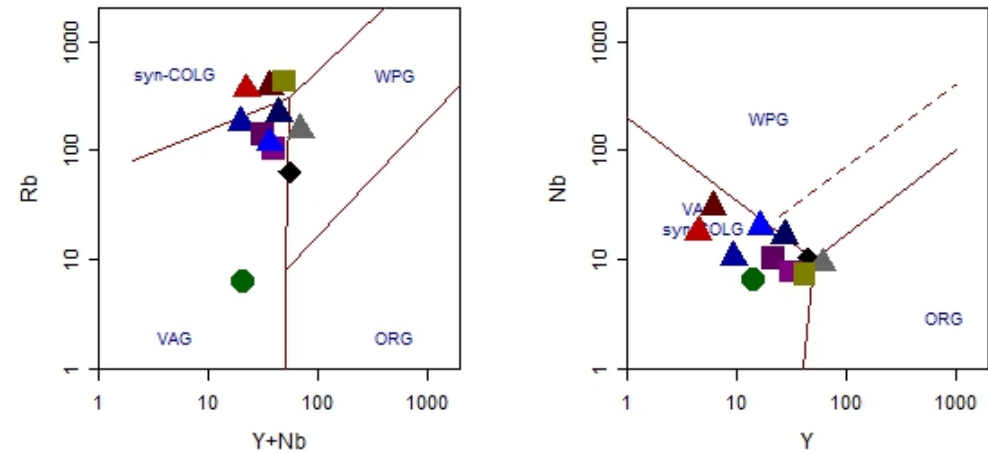

Fig. 15: (A) $(\mathrm{Y}+\mathrm{Nb})$ vs. $\mathrm{Rb}$ and (B) Y vs. $\mathrm{Nb}$ (In Ppm) Geotectonic Discrimination Diagram (After Pearce Et Al., 1984) Of Granite in the Northern Part of Birnin Gwari Schist Belt. ORG=Ocean Ridge Granites, Syn-COLG=Syn-Collisional Granites, VAG=Volcanic Arc Granites, WPG=Within Plate Granites (Symbol as in Fig. 3).
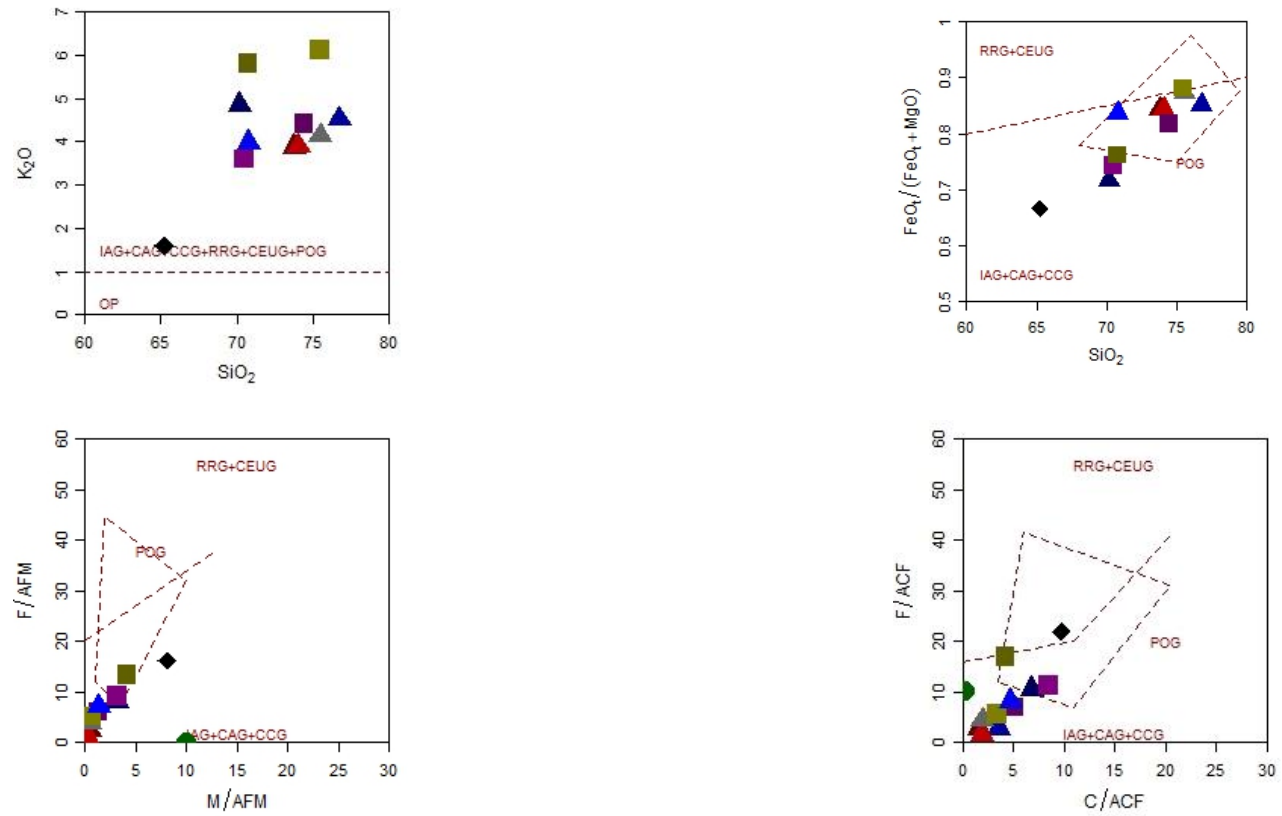

Fig. 16: Major Element Based Geotectonic Classification of Granite in the Northern Part of Birnin Gwari Schist Belt (A) $\mathrm{SiO}_{2}$ vs. $\mathrm{K}_{2} \mathrm{O}$; (B) M/AFM vs F/AFM; (C) $\mathrm{SiO}_{2}$ vs. $\mathrm{Fe}_{2} \mathrm{O}_{3} /\left(\mathrm{Fe}_{2} \mathrm{O}_{3}+\mathrm{Mgo}\right.$ ); (D) C/ACF vs. F/ACF (Maniar and Piccoli, 1989). Field IAG=Island Arc Granitoids, CAG=Continental Arc Granitoids, CCG=Continental Collision Granitoids, CEUG=Continental Epeirogenic Uplift Granitoids, OP=Oceanic Plagiogranites (Symbols as in Fig. 3). 

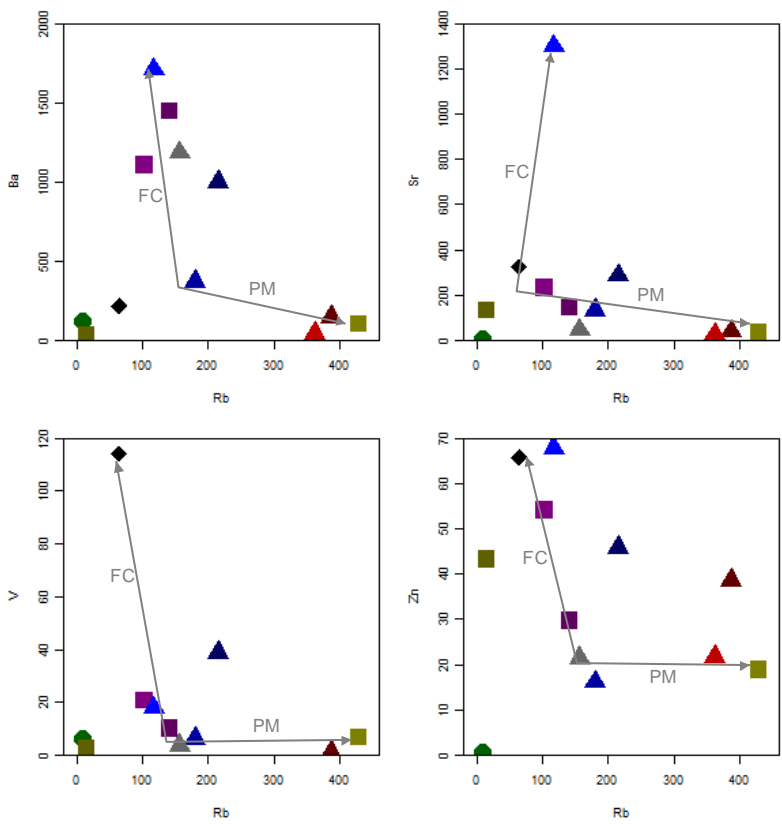

Fig. 17: Plot of Compatible Elements (Ba, Sr, V and Zn) Versus Incompatible Element (Rb) After Zorano et al. (2007) of Granite in the Northern Part of Birnin Gwari Schist Belt (Symbols as in Fig. 3).

\section{Discussions}

The Birnin Gwari mineral assemblage is quartz + K-feldspar + biotite + muscovite + plagioclase.

Wide variation in $\mathrm{SiO}_{2}$ content in the Birnin Gwari granite, granodiorite and quartzolite is usually interpreted as fractional crystallization and is characteristic of I-type granite (Azevedo and Nolan, 1998); its well-defined linear trend might be the result of either hybridization or fractionation (Chappell and Stevens, 1988; Hassanen et al., 1996). The positive and negative correlation with increasing $\mathrm{SiO}_{2}$ and the slightly scattered trend in $\mathrm{K}_{2} \mathrm{O}, \mathrm{Na}_{2} \mathrm{O}$ and $\mathrm{Al}_{2} \mathrm{O}_{3}$ suggests different geological processes, such as mixing or even distinct effects that should be investigated (Rollinson, 1993).

The high content of $\mathrm{Na}_{2} \mathrm{O}$ means that $\mathrm{Na}$ has not been removed from the source rocks (Chappell and White, 1992). $\mathrm{Na}_{2} \mathrm{O}$ values of $<3 \mathrm{wt}$ $\%$ in the quartzolite and two of the granite gneiss samples are characteristics of $\mathrm{S}$ - type granite while $\mathrm{Na}_{2} \mathrm{O}$ with $>3$ wt $\%$ in the granite and granodiorite are of I- type granite. Additionally, negative correlation of $\mathrm{P}_{2} \mathrm{O}_{5}$ with increasing $\mathrm{SiO}_{2}$ and low $\mathrm{K}_{2} \mathrm{O} / \mathrm{Na}_{2} \mathrm{O}$ ratios of granitoids in Birnin Gwari are characteristics of low-temperature I-type granites which may have resulted from fractional crystallization of and partial melting with pre-existing of peraluminous and calc-alkaline Birnin Gwari metasediments inherited from shale-greywacke and quartzose sedimentary protoliths derived from granodioritic and granite-quartz monzonite provenance (Oluyede et al., 2020b). Low temperature I-type granitoids are product of fractional crystallization of and partial melting with pre-existing heterogenous metapelliticamphibolitic igneous protolith (Chappell et al., 1988; Sun and Chen, 1992, Robert and Clemens, 1993; Ajaji et al., 1998). The high $\mathrm{K}_{2} \mathrm{O}$ content in granite $(4.14-4.86 \mathrm{wt} \%)$ is due to presence of large quantities of K-feldspar; typically high $\mathrm{K}_{2} \mathrm{O}$, negative $\mathrm{Nb}$ and $\mathrm{Ti}$ anomaly reinforces the calc-alkaline character and is characteristic of subduction-related granites in continental margin settings (Whalen et al., 1996; Soesoo, 2000; Ferre et al., 1998; Grigoriev and Pshenichny, 1998, Rottura et al., 1998). High concentration of Large Ion Lithophile Elements (LILE) is an indication of adundance of silicate minerals such as amphibole, biotite and feldspars. The positive $\mathrm{Pb}$ anomaly is more pronounced in all the rock types owing to the decay of the high uranium content.

The varied ratio Th/U of $0.02-1.45$ in some granite and 5.02 and 12 in others and granite gneiss and also 2.86 in granodiorite is an indication of contributions from crustal and mantle materials; rocks derived from the upper crust are characterized by ratio $\geq 4$, whereas ratio <4 has been related to a mantle contribution (Cullers and Podkovyrov, 2002; Roddaz et al., 2006); rocks derived from the upper crust are characterized by ratio $\geq 4$, whereas ratio $<4$ has been related to a mantle contribution (Cullers and Podkovyrov, 2002; Roddaz et al., 2006). Variation in content and behavior of lithophile elements ( $\mathrm{Ba}, \mathrm{Sr}$ and $\mathrm{Rb}$ ) is very useful in magmatic evolution controlled dominantly by fractional crystallization, partial melting or more complex processes (Dall Agnol et al 1999). Sr- $\mathrm{Rb}-\mathrm{Ba}$ and $\mathrm{Ba}-\mathrm{Rb}-\mathrm{Sr}$ ternary diagram revealed diverse granite trend such as high and low Ba-Sr granite (Tarney and Jones, 1994) "granodiorite and quartz diorite"; "normal", "anomalous" and "strongly differentiated" granite (El Bouseily and El Sokkary, 1975). Strongly differentiated granites are those that are distinctly impoverished in Ba but enriched in $\mathrm{Rb}$. They represent a very late stage of differentiation. "Anomalous granites" are those that have undergone chemical changes (e.g metasomatism) or were not formed by simple mechanism, while "normal granites" are those that are characterize by "normal" distribution of the three index lithophile elements (El Bouseily and El Sokkary 1975).

Birnin Gwari granitoids are also classified as subduction-zone magmatic rocks. For example "arc" magmatism are generated in convergent plate margins during active subduction of oceanic lithosphere, and is accompanied by the generation of basic to intermediate to acidic (basalt/tholeiite-andesite-dacite/rhyolite) plutonism and volcanism (Thiéblemont and Tegyey, 1994); this is supported by postorogenic plot of $\mathrm{Y}+\mathrm{Nb}$ vs $\mathrm{Rb}$ and $\mathrm{Y}$ vs $\mathrm{Nb}$ geotectonic discrimination diagram (after Pearce et al., 1984) where granite plot in the volcanic arc and syn-collision granitoid fields (Figs. 43 and 15). The trend and/or process of magmatic evolution of granitoids is seen from log of compatible element ( $\mathrm{Sr}, \mathrm{Ba}, \mathrm{Zn}$ and $\mathrm{V}$ ) versus $\log$ of incompatible element $(\mathrm{Rb})$ plot (Fig. 17), where differentiated liquids produced by partial melting will show a sub- horizontal trend whereas fractional crystallization will give rise to a sub-vertical trend (Cocherie, 1986; Zorano et al., 2007). The granitoids may have been derived from fractional crystallization of dioritic and granodioritic mantle material and partial melting and variable mixing pre-existing heterogenous crustally derived peraluminous and calc-alkaline Birnin Gwari metasediments inherited from shale-greywacke and quartzose sedimentary protoliths derived from granodioritic and granite-quartz monzonite provenance. Fractional crystallization, in constrast to partial melting, is a very powerful process to impoverish magmatic liquid in compatible elements. The discrimination between the two mechanisms is based on the behaviour of these elements. 
Consequently, it can be deduced that the mechanism of differentiation is fractional crystallization and partial melting of mantle materials and crustally derived metapellitic-amphibolitic igneous protolith in the Birnin Gwari schist belt (Sun and Chen, 1992, Robert and Clemens, 1993; Ajaji et al., 1998; Zorano et al., 2007).

The high-K calc-alkaline, calc-alkalic to alkali-calcic, magnesian to ferroan and peraluminous character of the Birnin Gwari granitoids make them similar to the Caledonian granitoids, otherwise variously known as high-K alkali-calcic granitoids, Post-orogenic granitoids, shoshonitic granitoids and K-rich calc-alkaline granitoids (Frost et al., 2001). A comparison of the geochemical characteristics of the granitic rocks in this study with those from other parts of Nigeria and the world (Table 6) reveal that they are very much similar to those of the Pan-African granitic rocks which occur in other schist belts in the SW, NW, SE and NE together with Jurassic (younger) Granites in the Northern Plateau areas (Obiora, 2012). Collision that resulted in the evolution of Birnin Gwari "subduction-zone magmatic rocks" took place under extensional and compressional regimes, and preceded by subduction of the lithosphere beneath an ancient oceanic crust at the eastern margin of the West African craton underneath the Tuareg shield (Obiora, 2006); this resulted in Eburnean and Pan-African deformations as well as Pan-African intrusion of calc-alkaline granites and volcanics (Danbatta, 2010) supported by the presence of basic to ultrabasic rocks such as extrusive basalt in the neighbouring Kushaka schist belt (Oluyede, 2020a) and calc-alkaline volcanics and hypabyssal rocks in the Anka schist belt (Agunleti et al., 2020) in the Nigerian sector. This has also resulted in characteristic ophiolitic complexes and a high positive gravity anomaly in a narrow zone within the Dahomeyide orogen, located at the southeastern margin of the West African Craton in Togo and Benin Republic (Schluter, 2005). Comparison of geochemical characteristics and ages of the Birnin Gwari granitoids with others Pan-African granitoids in different parts of Nigeria (notably in southwest, southeast, north-central, northwest, and northeast) revealed their similarities and their relation to the Pan-African granites also referred to as Older Granite. All the ages determined from the Pan-African granites showed consistency and correlates well (Table $1 \& 6$ ).

\section{Conclusions}

Petrographic and geochemical data have revealed three granitoids groups in the Biirnin Gwari granitoids: the biotite-hornblende granite and quartzolite (BHG), the biotite granite (BG) and the biotite \pm muscovite granite (BMG), with plagioclase, hornblende and biotite fractionation playing an important role during continuous fractional crystallization process. They are high-K calc-alkaline and shoshonitic, calc-alkalic to alkali-calcic, peraluminus and magnesianto ferroan suite of granitoid rocks bearing similarities to the Caledonian granitoids. The granitoids shows diverse trend such as high and low Ba-Sr granite; "granodiorite and quartz diorite"; "normal", "anomalous" and "strongly differentiated" granite based on the behavior of their lithophile elements (Ba, Sr and $\mathrm{Rb})$. The high $\mathrm{K}_{2} \mathrm{O}$ (> 2.5 wt \%) and $\mathrm{Na}_{2} \mathrm{O}\left(>3.0\right.$ wt $\%$ ) and low $\mathrm{K}_{2} \mathrm{O} / \mathrm{Na}_{2} \mathrm{O}$ ratios have characterized them as I-type granites. Other geochemical features include LILE and radioelement enrichment (some granite samples show depletion of $\mathrm{Rb}$ and $\mathrm{Ba}$ ), negative $\mathrm{Nb}, \mathrm{P}$ and $\mathrm{Ti}$ anomaly and low to high fractionation factor $(\mathrm{La} / \mathrm{Yb})_{\mathrm{N}}(6.74-45.14)$ which reinforces the calc-alkaline character and geochemical indication of subduction-zone magmatic rocks derived from fractional crystallization of dioritic mantle material and partial melting and variable mixing pre-existing heterogenous crustally derived peraluminous and calc-alkaline Birnin Gwari metasediments inherited from shalegreywacke and quartzose sedimentary protoliths derived from granodioritic and granite-quartz monzonite provenance in syn-collisional orogenic setting during the Pan-African Orogeny.

Table 6: Comparison of Geochemical Characteristics of the Granitic Rocks in Birnin Gwari Schist Belt with Those in other Parts of Nigeria and the

\begin{tabular}{|c|c|c|c|c|c|c|c|c|c|c|c|c|}
\hline \multicolumn{13}{|c|}{ World } \\
\hline $\begin{array}{l}\text { Geochemi } \\
\text { cal } \\
\text { Characteri } \\
\text { stics }\end{array}$ & $\begin{array}{l}\text { NW } \\
\text { Nigeria } \\
\text { (1) }\end{array}$ & $\begin{array}{l}\mathrm{NE} \\
\text { Nigeria } \\
(2)\end{array}$ & $\begin{array}{l}\text { North Ce } \\
\text { Nigeria } \\
(3 a)\end{array}$ & $(3 b)$ & $\begin{array}{l}\text { SE Nige } \\
\text { (4a) }\end{array}$ & (4b) & $\begin{array}{l}\text { SW } \\
\text { Nigeria } \\
(5)\end{array}$ & $\begin{array}{l}\text { Camero } \\
\text { on \& } \\
\text { Adama } \\
\text { wa } \\
\text { Massif } \\
(6)\end{array}$ & $\begin{array}{l}\text { Sudan } \\
\text { (7) }\end{array}$ & $\begin{array}{l}\text { Poland } \\
\text { (8) }\end{array}$ & $\begin{array}{l}\text { NE } \\
\text { Turkey } \\
\text { (9) }\end{array}$ & $\begin{array}{l}\text { This } \\
\text { Study } \\
\text { Birnin } \\
\text { Gwari }\end{array}$ \\
\hline $\begin{array}{l}\mathrm{SiO} 2 \mathrm{wt} \\
\%\end{array}$ & $63.5-70.4$ & $\begin{array}{l}62.72- \\
75.09\end{array}$ & $\begin{array}{l}71.34- \\
73.96\end{array}$ & $\begin{array}{l}66.61- \\
86.89\end{array}$ & $\begin{array}{l}63.47- \\
70.91\end{array}$ & $\begin{array}{l}65.4- \\
69.89\end{array}$ & $\begin{array}{l}64.17- \\
77.19\end{array}$ & $\begin{array}{l}64.75- \\
76.27\end{array}$ & $\begin{array}{l}57.66- \\
72.06\end{array}$ & $60-76$ & $53-85$ & $\begin{array}{l}65.24- \\
82.42\end{array}$ \\
\hline $\begin{array}{l}\mathrm{Na}_{2} \mathrm{O}- \\
\mathrm{K}_{2} \mathrm{O} \text { vs } \\
\mathrm{SiO}_{2}\end{array}$ & $\begin{array}{l}\text { Calc } \\
\text { alkaline }\end{array}$ & $\begin{array}{l}\text { Transalka } \\
\text { line to } \\
\text { non- } \\
\text { alkaline }\end{array}$ & NA & NA & $\begin{array}{l}\text { Calc- } \\
\text { alkaline }\end{array}$ & $\begin{array}{l}\text { Calc- } \\
\text { alkaline }\end{array}$ & $\begin{array}{l}\text { Calc- } \\
\text { alkaline }\end{array}$ & $\begin{array}{l}\text { Calc- } \\
\text { alkaline }\end{array}$ & $\begin{array}{l}\text { Calc- } \\
\text { alkaline }\end{array}$ & $\begin{array}{l}\text { Alkalin } \\
\text { e to } \\
\text { sub- } \\
\text { alkalin } \\
\text { e }\end{array}$ & $\begin{array}{l}\text { Calc- } \\
\text { alkalin } \\
\mathrm{e}\end{array}$ & $\begin{array}{l}\text { Calc- } \\
\text { alkaline }\end{array}$ \\
\hline $\begin{array}{l}\mathrm{K}_{2} \mathrm{O} \text { vs. } \\
\mathrm{SiO}_{2}\end{array}$ & NA & $\begin{array}{l}\text { High K } \\
\text { Calc- } \\
\text { alkaline }\end{array}$ & NA & NA & $\begin{array}{l}\mathrm{FeO} \\
\text { enriche } \\
\mathrm{d}\end{array}$ & $\begin{array}{l}\text { High K } \\
\text { Calc- } \\
\text { alkaline, } \\
\text { Transalka } \\
\text { line, Non- } \\
\text { alkaline }\end{array}$ & $\begin{array}{l}\text { High K } \\
\text { Calc- } \\
\text { alkaline }\end{array}$ & $\begin{array}{l}\text { High K } \\
\text { Calc- } \\
\text { alkaline }\end{array}$ & $\begin{array}{l}\text { High K } \\
\text { Calc- } \\
\text { alkaline }\end{array}$ & $\begin{array}{l}\text { High K } \\
\text { Calc- } \\
\text { alkalin } \\
\text { e to } \\
\text { shosho } \\
\text { nite }\end{array}$ & $\begin{array}{l}\text { Mediu } \\
\text { m to } \\
\text { High K } \\
\text { Calc- } \\
\text { alkalin } \\
\text { e }\end{array}$ & $\begin{array}{l}\text { High K } \\
\text { calc- } \\
\text { alkaline }\end{array}$ \\
\hline $\begin{array}{l}\mathrm{Fe}- \\
\text { number }\end{array}$ & $\begin{array}{l}\text { Magnesia } \\
\mathrm{n}\end{array}$ & $\begin{array}{l}\text { Ferrirero } \\
\text { us to } \\
\text { High } \\
\text { Ferrifero } \\
\text { us }\end{array}$ & $\begin{array}{l}\text { Magnes } \\
\text { ian }\end{array}$ & $\begin{array}{l}\text { Magnes } \\
\text { ian }\end{array}$ & $\begin{array}{l}\text { Magnes } \\
\text { ian }\end{array}$ & Ferroan & Ferroan & $\begin{array}{l}\text { Ferroan } \\
\& \\
\text { Magnes } \\
\text { ian }\end{array}$ & $\begin{array}{l}\text { Ferroan } \\
\& \\
\text { Magnes } \\
\text { ian }\end{array}$ & Femic & NA & $\begin{array}{l}\text { Ferroan } \\
\& \\
\text { Magnes } \\
\text { ian }\end{array}$ \\
\hline MALI & $\begin{array}{l}\text { Alkalic- } \\
\text { calcic }\end{array}$ & NA & $\begin{array}{l}\text { Alkalic } \\
\text { - Calcic }\end{array}$ & $\begin{array}{l}\text { Calcic } \\
- \\
\text { Alkalic }\end{array}$ & $\begin{array}{l}\text { Alkalic } \\
- \\
\text { Calcic } \\
\text { to } \\
\text { Calcic } \\
\text { Alkali }\end{array}$ & $\begin{array}{l}\text { Alkalic- } \\
\text { Calcic to } \\
\text { Alkali }\end{array}$ & $\begin{array}{l}\text { Alkalic } \\
- \\
\text { Calcic } \\
\text { to } \\
\text { Calcic } \\
\text { Alkali }\end{array}$ & $\begin{array}{l}\text { Calcic } \\
- \\
\text { Alkalic }\end{array}$ & $\begin{array}{l}\text { Calcic - } \\
\text { Alkalic }\end{array}$ & $\begin{array}{l}\text { Alkalic } \\
\text { - Calcic }\end{array}$ & NA & $\begin{array}{l}\text { Calc- } \\
\text { Alkali } \\
\text { to } \\
\text { alkali- } \\
\text { calcic }\end{array}$ \\
\hline ASI & $\begin{array}{l}\text { Metalumi } \\
\text { nous \& } \\
\text { peralkalin } \\
\text { e for } \\
\text { syenite }\end{array}$ & $\begin{array}{l}\text { Met } \\
\text { aluminou } \\
\text { s }\end{array}$ & $\begin{array}{l}\text { Per- } \\
\text { alumin } \\
\text { ous }\end{array}$ & NA & $\begin{array}{l}\text { Per } \\
\text { alumin } \\
\text { ous }\end{array}$ & $\begin{array}{l}\text { Met } \\
\text { aluminous }\end{array}$ & $\begin{array}{l}\text { Met } \\
\text { Alumin } \\
\text { ous }\end{array}$ & $\begin{array}{l}\text { Met } \\
\text { alumin } \\
\text { ous }\end{array}$ & $\begin{array}{l}\text { Met } \\
\text { alumin } \\
\text { ous }\end{array}$ & NA & $\begin{array}{l}\text { Met } \\
\text { alumin } \\
\text { ous }\end{array}$ & $\begin{array}{l}\text { Per } \\
\text { alumin } \\
\text { ous }\end{array}$ \\
\hline $\mathrm{Eu}$ & NA & Moderate & Pronou & NA & NA & Pronounc & & Pronou & Modera & NA & -- & Weak \\
\hline
\end{tabular}


anomaly

$\begin{array}{ll}\text { Eu } & \text { nce Eu } \\ \text { anomaly } & \text { anomal }\end{array}$

Explanation: No 1: Olanrewaju and Rahaman (1982); Egbuniwe et al., (1985); 2: Rahaman et al., (1998); 3a: Onyegocha (1986); 3b: Obiora and Ukaegbu (2007); 4a:Rahaman et al., (1988); 4b: Obiora, (2012); 5: Okonkwo and Winchester, 2004; 6: Haruna, (2014); 7: Lissan \& Bakheit, (2011); 8: Baginski et al., (2007); Karacic et al., (2008). $3 \mathrm{a}$ and b were computed by Obiora and Ukaegbu, (2009).

\section{Acknowledgement}

The authors acknowledge the assistance of Mr Adekunle for his assistance as a guide during the field mapping exercise. We are indebted to the staff of Geochronology Laboratory for their efforts in carrying out the geochemical analysis for the whole rock major and trace elements and Dr Abdulrasak Garba, Director General, Nigeria Geological Survey Agency, Abuja for his assistance in the REE analysis. Insights and contributions of Prof. Abba and Prof. Ajibade in the course of this work are greatly acknowledged. The efforts of Prof. Najime Tavershima, Head, Geology Department, Dr S. S. Magaji, Mr. A.K. Amuda and Mr Animashaun of the Department of Geology, Ahmadu Bello University Zaria are equally acknowledged. The help of Peter Nagl, University of Vienna, with the whole rock geochemical analysis is also acknowledged.

\section{References}

[1] Ajaji, T., Weis, D., Giret, A. and Bouabdellah, M. (1998). Coeval potassic and sodic calc-alkaline series in the post-collisional Hercynian Tanncherfi intrusive complex, Northeastern Morrocco: geochemical, isotopic and geochronological evidence. Lithos 45, 371-393. https://doi.org/10.1016/S0024-4937(98)00040-1.

[2] Ajibade A. C., Anyanwu, N. P. C., Okoro, A. U. and Nwajide, C. S. (2008). The Geology of Minna area. Nigeria Geological Survey Agency Bulletin No 43.

[3] Agunleti, Y. S., Najime, T., Ibrahim, A. A. and Magaji, S. S. (2020). Geology and petrographic studies of rocks in Anka sheet 52, Northwestern Nigeria. Journal of Environmental and Earth Sciences. 10, 53-66.

[4] Akinola, O. O., Talabi, A. O. and Muhammad, H. R. (2017). Petrostructural Features of Metaconglomerate in Igarra and Otuo, South-Western Nigeria. Asian Journal of Earth Sciences, 10, 33-43. https://doi.org/10.3923/ajes.2017.33.43.

[5] Baginski, B., Duchesne, J., Martin, H. and Wiszniewska, J., (2007). Isotopic and geochemical constraints on the evolution of the Mazury granitoids, NE Poland. AM Monogragh No. 1, 1130.

[6] Batchelor, R. A, Bowden, P. (1985): Petrogenetic interpretation of granitoid rock series using multicationic parameters. Journal of Chemical Geology 48, 43-55 https://doi.org/10.1016/0009-2541(85)90034-8.

[7] Boynton W.V. 1984. Cosmochemistry of the rare earth elements; meteorite studies. In: Henderson P. (Ed.). Rare Earth element geochemistry. Amsterdam: Elsevier. 63-114. https://doi.org/10.1016/B978-0-444-42148-7.50008-3.

[8] Chappell, B.W and White, A.J.R. (1974): Two contrasting granite types. Pacific journal geology.8: pp. 173-174.

[9] Chappell B. W. and Stephens W. E. (1974). Origin of infracrustal (I-type) granite magmas. Transactions of the Royal Society of Edinburgh: Earth Sciences 79, 71-86. https://doi.org/10.1017/S0263593300014139.

[10] Chappell B. W. Bryant, C. J., Wyborn, D., White A. J. R and Williams I. S. 1998. High- and low-temperature I-type granites. Resource Geology 48, 225-226. https://doi.org/10.1111/j.1751-3928.1998.tb00020.x.

[11] Cocherie, A. 1986. Systematic Use of Trace Element Distribution on Patterns in Log-Log Diagrams for Plutonic Suites. Geochimica et Cosmoshimica Acta, 50, 2517-2522. https://doi.org/10.1016/0016-7037(86)90034-7.

[12] Cox, K. G., Bell, J. D., Pankhurst, R. J., (1979). The interpretation of igneous rocks, George, Allen and Unwin, London. https://doi.org/10.1007/978-94-017-3373-1.

[13] Cullers R. L., Podkovyrov V. L., (2002). The source and origin of terrigenous sedimentary rocks in the Mesoproterozoic Ui group, Southeastern Russia. Precambrian Research. 117(3):157-183. https://doi.org/10.1016/S0301-9268(02)00079-7.

[14] Dada, S. S. 1998. Crust-forming ages and Proterozoic crustal evolution in Nigeria: of current interpretations. Precambrian Research 87, 65-74. https://doi.org/10.1016/S0301-9268(97)00054-5.

[15] Dada, S.S., Lancelot, J.R., Briqueu, L., 1989. Age and origin of the annular charnockitic complex at Toro, Northern Nigeria: U--Pb and RbSr evidence. Journal of African Earth Sciences, 9, pp. 227-234. https://doi.org/10.1016/0899-5362(89)90066-3.

[16] Dada, S. S., Birck, J. L., Lancelot, J. R. and Rahaman, M. A. (1993): Archean migmatite-gnesis complex of North Central Nigeria: its geochemistry, Petrogenesis and crustal evolution. In: 16th International Colloquium on African Geology, Mbabane, Swaziland, Extended Abstracts, 1: pp. 97-102.

[17] Danbatta. U. A. 2002. Rb-Sr Isochron Dating of Granitoids from the Kazaure Schist Belt, NW Nigeria. Global Journal of Pure and Applied Sciences 8 (3). 319-322. https://doi.org/10.4314/gipas.v8i3.16015.

[18] Danbatta. U. A. 2010. On the evolution of Kazaure Schist Belt of NW Nigeria. Global Journal of Geological Sciences 8 (2). $207-216$. https://doi.org/10.4314/gjgs.v8i2.62775.

[19] Ekwueme, B.N. and Kroner, A., 1998. Single zircon evaporation ages from the Oban Massif, southeastern Nigeria. Journal of African Earth Sciences, 26, 195 - 205. https://doi.org/10.1016/S0899-5362(98)00005-0.

[20] Ekwueme, B.N. and Pidgeon, R.T. (2001). The Oldest Rocks in West Africa: SHRIMP Zircon Age for Early Achean Migmatitic Orthogneiss at Kaduna, Northern Nigeria. Journal of Geology, university of Chicago,109, 399-406. https://doi.org/10.1086/319979.

[21] El Bouseily, A. M and El-Sokkary, A. A., 1975. The relationship between Rb, Sr and Ba in granitic rocks. Chemical Geology. 16, 174-189. https://doi.org/10.1016/0009-2541(75)90029-7.

[22] Egbuniwe, I., Fitches, W., Bently, M., and Snelling L., 1985. Late Pan-African syenite-granite plutons from NW Nigeria. Journal of African Earth Sciences, 9, 227-234.

[23] Ezepue, M. C and Odigi, M. I., 1993. Petrology and geochemistry of monzodiorite, granodiorite and granites from the Precambrian terrain between Kabba and Lokoja, SW Nig. Jour. Min. Geol; 30, (1): 1-9.

[24] Ferre, E. C., Caby, R., Peucat, J. J., Capdevila, I. R., and Monie, P., 1998. Pan-African post-collisional, ferro-potassic granite and quartz-monzonite plutons of Eastern Nigeria. Lithos, 45, pp. 255 278. https://doi.org/10.1016/S0024-4937(98)00035-8.

[25] Fitches, W.R., Ajibade A. C., Egbuniwe I.G., Holt R. W., and Wright J.B. (1985): Late Proterozoic Schist Belts and Plutonism in NW Nigeriae, Geological Society of London, 142: pp. 319- 337. https://doi.org/10.1144/gsigs.142.2.0319.

[26] Garba, I. 2002. Late Pan-African tectonics and origin of Gold mineralization and Rare-metal pegmatites in the Kushaka schist belt, northwestern Nigeria. Journal of Mining and Geology. 38, 1, 1-12. https://doi.org/10.4314/jmg.v38i1.18768.

[27] Girei, M. B. 2015. Geology, geochemistry and petrogenesis of granite suites and pegmatites in the northern part of Mandara Hills Gwoza Sheet 114 Northeastern Nigeria. Unpublished M. Sc. Thesis, Ahmadu Bello University, Zaris. 
[28] Goodenough, K. M., Lusty, P. A. J., Roberts, N. M. W., Key, R. M. and Garba, A. 2014. Post-collisional Pan-African granitoids and rare metal pegmatites in western Nigeria: Age, petrogenesis, and the 'pegmatite conundrum'. Lithos 200, 22-34 https://doi.org/10.1016/j.lithos.2014.04.006.

[29] Grant, N. K. 1978. Structural distinction between metasedimentary cover and an underlying basement in the 600 m.y. old Pan-African domain of Northwestern Nigeria, West African. Geological Society America Bulletin 89, 50-58. https://doi.org/10.1130/00167606(1978)89<50:SDBAMC>2.0.CO;2.

[30] Grigoriev, S. I. and Pshenichny, C. A., 1998. Late Mesozoic post-collisional intermediate to silicic magmatism in the Badjal area, far east of Russia. Lithos 45, 457-468. Kröner, A., Hassanen M.A., El-nisr S.A., and Mohamed F.H (1996): Geochemistry and petrogenesis of Pan-African I-type granitoids at Gabal Igla Ahmar, Eastern Desert, Egypt. Journal of African Earth Science 22, (1): pp. 29-42 https://doi.org/10.1016/S00244937(98)00044-9.

[31] Harris, N. B. W., Pearce, J. A. and Tindle, A. G., 1986. Geochemical characteristics of collision-zone magmatism. In: Coward, M. P. and Reis, A. C. (eds.) Collision tectonics. Special Publication of the Geological Society, 19, pp. 67 -81. https://doi.org/10.1144/GSL.SP.1986.019.01.04.

[32] Igonoh, E. E., and Abimbola, A. F. 1971. Geochemistry of Pan-African Granitoids, Southwest Nigeria: Evidence of Magmatic Mixing, Journal of Geography, Environment and Earth Science International 5(4): 1-17 https://doi.org/10.9734/JGEESI/2016/19041.

[33] Irvine, T. N., and Baragar, W. R. A. 1971. A Guide to the Chemical Classification of Common Volcanic Rocks. Canadian Journal of Earth Sciences, 8, (5), 523-548. https://doi.org/10.1139/e71-055.

[34] Karacik, Z., Yilmaz, Y., Pearce, J. A. and Ece, O. I., 2008. Petrochemistry of the south Marmara granitoids, northwest Anatolia, Turkey. International Journal of Earth Sciences (Geol Rundsch), 97, pp. 1191-1200. https://doi.org/10.1007/s00531-007-0222-y.

[35] Lissan, H. N., Bakheit, A. K.., 2011. Geochemistry and geotectonic setting of Neoproterozoic Granitoids from Artoli Area, Berber Province Northern Sudan. Journal of Applied Sciences. 11 (5), 752-767. https://doi.org/10.3923/jas.2011.752.767.

[36] Makanjuola, A.A. 1982. A Review of the Petrology of the Nigerian syenites. Journal of Mining and Geology, $19(2), 114$.

[37] Maniar, P. D. and Piccoli, P. M., 1989. Tectonic discrimination of granitoids. Geological Society of American Bulletin, 101 , pp. 635 -643. https://doi.org/10.1130/0016-7606(1989)101<0635:TDOG>2.3.CO;2.

[38] McCurry, P. 1976. The geology of the Precambrian to Lower Palaeozoic of northern Nigeria- a review. In: Geology of Nigeria. C.A. Kogbe (Ed). Elizabethan Publishing Company. Lagos, 15-39.

[39] Miyashiro A (1978). Nature of alkalic volcanic rock series. Contrib. Mineral Petrol. 66: 91-104.

[40] Obiora, S. C., 2006. Petrology and Geotectonic Setting of B asement Complex Rocks around Ogoja, Southeastern Nigeria. Ghana Journal of Science, 46, pp. 13 - 25. https://doi.org/10.4314/gjs.v46i1.15912.

[41] Obiora, S. C. (1986): Chemical characterization and tectonic evolution of hornblende-biotite granitoids from the Precambrian Basement Complex around Itowanye and Katsina-Ala, southeastern Nigeria. Journal of Mining and Geology Vol. 48(1): pp. 13-29.

[42] O'ec Connor, J. T. (1965). A classification for quartz-rich igneous rocks based on feldspar ratios. US Geological Survey, Professional Papers 52(5): pp. $79-84$.

[43] Odewumi, S. C., Olarewaju, V. O. (2013) Petrogenesis and Geotectonic Settings of the Granitic Rocks of Idofin-osi-eruku Area, Southwestern Nigeria using Trace Element and Rare Earth Element Geochemistry. Journal of Geology and Geosciences 2: 109. https://doi.org/10.4172/23296755.1000109

[44] Okonkwo, C. T. and Winchester, J. A., 2004. Geochemistry of granitic rocks in Jebba area, southwestern Nigeria. Journal of Mining and Geology, Vol. 40(2), pp. 95 - 100. https://doi.org/10.4314/jmg.v40i2.18814.

[45] Oluyede, O. K., Garba, I., Danbatta, U., Ogunleye, P. and Klötzli, U. (2020). Field occurrence, petrography and structural characteristics of basement rocks of the northern part of Kushaka and Birnin Gwari schist belts, northwestern Nigeria. Journal of Natural Sciences Research. ISSN (Paper) 2224-3186 (Online) 2225-0921 https://doi.org/10.7176/JNSR.

[46] Oluyede, O. K., Garba, I., Danbatta, U., Ogunleye, P. and Klötzli, U. (2020). Geochemistry and petrogenesis of banded and granitic gneisses of the northern part of Kushaka schist belts northwestern Nigeria. Journal of Environmental and Earth Science. ISSN (Paper) 2224-3216 (Online) 22250948 https://doi.org/10.7176/JEES.

[47] Onyeagocha A. C. (1986): Geochemistry of basement granitic rocks from northcentral Nigeria. Journal of African Earth Science 5(2): pp. $651-657$. https://doi.org/10.1016/0899-5362(86)90032-1.

[48] Oyawoye, M.O., 1972. The Basement Complex of Nigeria in Dessauvagie, T.F.J. and Whiteman, A.J. (eds). African Geology. Ibadan University Press, Ibadan, pp. $67-99$.

[49] Oyinloye, A. O. and Ojo, A. O. (1988). Physical and Mineral Evaluation of lay Deposits at Ado-Ekiti. Journal of Techno-Science, (2) 1 Pg 49-52.

[50] Olarewaju, V. O. (1988). "Petrology and geochemistry of the charnockitic and associated granitic rocks of Ado-Ekiti, Akure, S.W. Nigeria". In: Precambian Geology of Nigeria. pp 231-239. Geological Survey of Nigeria Publication.

[51] Olarewaju, V. O. and Rahaman, M. A., 1982. Petrology and Geochemistry of Older Granites from some parts of Northern Nigeria. Journal of Mining and Geology, 18(2), pp. 16-28.

[52] Pearce, J. A. Harris, N. B. W. and Tindle, A. G. W. 1984. Trace Element Discrimination Diagrams for the Tectonic İnterpretation of Granitic Rocks. Journal of Petrology, 25, (4), 956-983. https://doi.org/10.1093/petrology/25.4.956.

[53] Peccerillo, A., and Taylor, S. R. (1976): Geochemistry of Eocene calc-alkaline volcanic rocks from the Kastamonu area, northern Turkey. Contributions to Mineralogy and Petrology, 58: pp. 63-81. https://doi.org/10.1007/BF00384745.

[54] Rahaman, M. A. 1976. Review of the basement geology of southwestern Nigeria. In: Geology of Nigeria. (Edited by C. A. Kogbe). Elizabethan Publishing Company Lagos, 41-58

[55] Rahaman, M. A. 1988. Recent advances in the study of the basement complex of Nigeria. In: Precambrian Geology of Nigeria. (Eds. Oluyide et al.) a publication of the Geological Survey Nigeria. 71-43.

[56] Roberts, M. P. and Clemens J. D. 1993. The origin of high-potassium calc-alkaline I-type granitoids. Geology 21, 825-828. https://doi.org/10.1130/0091-7613(1993)021<0825:OOHPTA>2.3.CO;2.

[57] Roddaz M, Viers J, Brusset S, Baby P, Boucayrand C, Hérail G. (2006). Controls on weathering and provenance in the Amazonian foreland basin: Insights from major and trace element geochemistry of Neogene Amazonian sediments. Chemical Geology. 226 (1) $31-65$. https://doi.org/10.1016/j.chemgeo.2005.08.010.

[58] Rollinson, H. R., 1993. Using Geochemical Data: Evaluation, Presentation and Interpretation. Longman Group, Uk Ltd. Co-published in the United States with John Wiley and Sons, New York, 352.

[59] Rottura, A., Bargossi, G. M., Caggianeli, A., Del Moro, A., Visona, D. and Tranne, C. A. 1998. Origin and significance of the Permian high-K calc-alkaline magmatism in the central-eastern Southern Alps, Italy. Lithos 45, (1-4) 329-348. https://doi.org/10.1016/S0024-4937(98)00038-3.

[60] Russ, W. 1957. The geology of parts of Niger, Zaria and Sokoto provinces with reference to the occurrence of gold. Geological Survey Nigeria Bulletin 29.

[61] Schluter, T., 2005. Geological Atlas of Africa: With Notes on Stratigraphy, Tectonics, Economic Geology, Geohazards, Geosites and Geoscientific Education of Each Country. 2nd Edition. Springer, 272p.

[62] Streckeisen, A., (1976). To each plutonic rock its proper name. Earth Science Review 6: 181-217.

[63] Sun S. S. and McDonough, W. F. (1989). Chemical and isotopic systematics of oceanic basalts: implications for mantle composition and processes. In: Saunders A.D., Norry M.J. (Eds.). Magmatism in the ocean basins. Geological Society of London, Special Publication, 42:313-345. https://doi.org/10.1144/GSL.SP.1989.042.01.19.

[64] Sun, L. M. and Chen, J. C. (1992) Geochemical study of granites from Chimen (Quemoy) and Hong Kong, Southeastern China. Journal of Southeast Asian Earth Sciences 7, (4), 237-245. https://doi.org/10.1016/0743-9547(92)90003-T.

[65] Tarney J. \& Jones C.E. 1994. Trace element geochemistry of orogenic igneous rocks and crustal growth models. Journal of the Geological Society, 151(5):855-868. https://doi.org/10.1144/gsjgs.151.5.0855. 
[66] Thiéblemont and Tegyey, (1994). D. Thiéblemont and M. Tegyey, Une discrimination géochimique des roches différenciées témoin de la diversité d'origine et de situation tectonique des magmas calco-alcalins, Comptes Rendus de l'Académie des Sciences Paris 319 (1994), pp. $87-94$.

[67] Tubosun, I. A., Lancelot, J. R., Rahaman, M. A., Ocan, O., 1984. U-Pb Pan-African ages of two charnockite-granite association from southwestern Nigeria. Contribution to Mineralogy and Petrology 88, 188-195. https://doi.org/10.1007/BF00371422.

[68] Turner, D. C. 1983: Upper Proterozoic schist belts in the Nigerian sector of the Pan African Province of West Africa. Precambrian Research 21, 579. https://doi.org/10.1016/0301-9268(83)90005-0.

[69] Ukwang, E., and Ekwueme, B. N. (2009): Geochemistry and geotectonic study of granitic rocks of southwest Obudu Plateau, southeastern Nigeria. Journal of Mining and Geology, 45: pp. 73-82.

[70] Van Breemen, O., Pidgeon, R. T. and Bowden, P. 1977. Age and isotopic studies of some Pan-African granites from North-central Nigeria. Precambrian Research 4, 319-407. https://doi.org/10.1016/0301-9268(77)90001-8.

[71] Whalen J. B., Currie K. L. and Chappell B. W. 1987. A-type granites: Geochemical characteristics, discrimination and petrogenesis. Contributions Mineralogy Petrology 95: 407-419. https://doi.org/10.1007/BF00402202.

[72] White, A. J. R., (2001) Water, Restite and Granite Mineralization. Australian Journal of Earth Sciences, 48 , 551-555. https://doi.org/10.1046/j.1440-0952.2001.00878.x.

[73] Zorano S. S; Martin H., Jean-jacques P; Emanuel F. J. and Maria H. F. M. (2007): Calc-Alkaline Magmatism at the Archean-Proterozoic Transition: the Caico Basement Complex (NE Brazil) Journal of Petrology 48 (11): pp. 2149-2185 https://doi.org/10.1093/petrology/egm055. 